\title{
Priest, Preacher, Pastor: Research on Clerical Office in Early Modern Europe
}

\author{
Luise Schorn-Schütte
}

\section{Introduction and Issues}

$\mathrm{S}$ OCIAL historians have made considerable progress over the last decades in their research on social elites. This is especially true for the early modern period, in which the bourgeoisie gained importance as instrumental agents in the centralization of political power throughout Europe.' The clergy of the three Christian confessions that shaped the religious landscape after the Reformation participated decisively in this process. Researchers have scarcely investigated this process, however, and have paid even less attention to a comparison of confessions. The traditional and still prevalent view contrasts the Catholic Church, allied with the higher aristocracy and under the pope's rule, with the Protestant Church, dominated by the bourgeoisie and under state rule. This view is assumed to characterize sufficiently the clergy's function in the process of early modern political, social, and religious change.

Once the multitude of preconceptions inherited from the nineteenth century, and especially from the Kulturkampf, have been eliminated, however, it becomes obvious that we must revise both the thesis of confessional difference and the thesis of the clergy's role purely as an instrumental agent in the centralization of political power. ${ }^{2}$ Research on the creation of confessional cultures,

1. H. Schilling has reviewed recent research on the period from the mid-sixteenth to the mideighteenth centuries in Die Stadt in der Frühen Neuzeit (Munich, 1993). There has been much recent controversy over the importance of the bourgeoisie/middle classes in the transition from the eighteenth to the ninetecnth centuries; see both J. Kocka, ed., Bildingsbürgertum im 19. Jahrhundert, Part 4: Politischer Einfluss und gesellschaftliche Formation (Stuttgart, 1989), and L. Gall, ed., Stadt und Bürgertum im Übergang von der traditionalen zur modernen Gesellschaft (Munich, 1996).

2. An attempt for the sixteenth and seventeenth centuries, L. Schorn-Schütte, "The Christian Clergy in the Early Modern Holy Roman Empire: A Comparative Social Study," Sixteenth Century Journal 29, no. 3 (1998): 717-32, which cites additional literature. A research project from an international perspective, "The Early Modern Clergy: A Comparison of the Social Biographies of Protestant Pastors and Catholic Pastoral Clergy in the Old Empire, the Polish Aristocratic Republic and the Swiss Confederation," funded by the Volkswagen-Stiftung, is associated with Luise Schorn-Schütte at the Johannes Wolfgang Goethe-University Frankfurt am Main. This paper draws on the first results of this research project. A. Moritz, student assistant with this project, created the tables in the Appendix. R. Dürr, a collaborator, summarized some of her findings in "Geistlichkeit in der Frühen Neuzeit: Vergleichende Studien über den katholischen und

Central European History, vol. 33, no. 1, 1-39 
together with the increasingly urgent question about the normative development of the early modern social order have made it clear that the clergy cannot simply be described as "agents of the state." ${ }^{\text {On }}$ On the contrary, all three confessions witnessed the development of similar groups of clerical officeholders, each with their own understanding of their role as clergy (a Sonderbeursstsein), ${ }^{4}$ who were capable of counteracting the centralizing function intended for them by the political ruler. The reformulation of the relationship between religion and politics legitimized a space for political action ${ }^{5}$ in which the clergy assumed a thoroughly independent role. The characterization of this role is still in its beginning stages. If one follows the Anglo-Saxon approach, which characterizes political language as an approach to and a medium for political action ("words are deeds"), ${ }^{6}$ then the formulation in both Protestantism and Catholicism of a "Christian doctrine of the state" with practical consequences is of central significance for the legitimization of the clergy's intentions to shape the world in which they lived.?

protestantischen Seelsorgeklerus 1550-1750," in Die Diözese Hildesheim in Vergangenheit und Gegenwart 65 (1997): 255-62; S. Tode, another collaborator, has published results from Danzig and Ermland in Unsere ermlandische Heimat 44, no. 1 (1998). U. Pfister has given a broad confessional comparison for Graubünden in his study published in this issue.

3. L. Schorn-Schütte discusses the Protestant side at length in Evangelische Geistlichkeit in der Frühneuzeit: Deren Anteil an der Entfaltung frühmoderner Staatlichkeit und Gesellschaft, (Gütersloh, 1996); W. Sommer, Gottesfurcht und Fürstenherrschaft: Studien zum Obrigkeitsverständnis Johann Arndts und lutherischer Hofprediger zur Zeit der altprotestantischen Orthodoxie (Göttingen, 1988); M. Kruse, Speners Kritik am landesherrlichen Kirchenregiment und ihre Vorgeschichte (Witten, 1971), which has prompted my own thoughts in this paper. Cf. F. W. Graf, "Protestantismus II. Kulturbedeutung," in Theologische Realenzyklopädie [henceforth TRE 18 (Berlin, 1997), 551-80, esp. 569-71. On the relevance of this statement for the Catholic side, see Schorn-Schütte, "Christian Clergy," and R. Po-chia Hsia, Gesellschaft und Religion in Münster: 1535-1618 (Münster, 1989). The study by A. Nelson Burnete, "Basel's Rural Pastors as Mediators of Confessional and Social Discipline," also in this issue, follows this approach for the history of Basel's clergy in the sixteenth century, but there are nuances due to the specific situation of the city and territory of Basel.

4. This term first used by $L$. Schorn-Schütte, "Prediger an protestantischen Höfen der Frühneuzeit: Zur politischen und sozialen Stellung einer neuen bürgerlichen Führungsgruppe in der höfischen Gesellschaft des 17. Jahrhunderts," in Bürgerliche Eliten in den Niederlanden und in Nordwestdeutschland, ed. H. Schilling and H. Diederiks (Cologne, 1985), 275-336.

5. Cf. the stimulating but controversial essay by N. Haag, "Zum Verhältnis von Religion und Politik im konfessionellen Zeitalter-system- und diskurstheoretische Überlegungen am Beispiel der Lutherischen Erneuerung in Württemberg und Hessen, Archiv für Reformationsgeschichte [hereafter $A R G$ ], 88 (1997): 166-98, esp. 178-79.

6. Q. Skinner and J. G. A. Pocock follow this approach; for an introduction see A. Pagden, ed., The Language of Political Theory in Early Modern Europe (Cambridge, 1987); for a criticial discussion cf. J. Tully, ed., Meaning and Context: Quentin Skinner and his Critics (Princeton, 1988). Good introductions in German include M. Richter, "Pocock, Skinner und die geschichtlichen Grundbegriffe," in Alteuropa-Ancien Regime-Frühe Neuzeit, ed. H. E. Bödeker and E. Hinrichs (Stuttgart, 1991), 134-74, and H. Rosa, "Ideengeschichte und Gesellschaftstheorie: Der Beitrag der "Cambridge School' zur Metatheorie," Politische Vierteljahresschrift 35 (1994): 197-223.

7. See L. Schorn-Schütte, "Die Drei-Stände-Lehre im reformatorischen Umbruch," in Die Reformation als Umbruch, ed. B. Moeller (Gütersloh, 1998), 435-61. On the politica christiana, see 
The contrast between the goal of centralizing political authority and its implementation at the local level is by no means a phenomenon limited to the claims and competencies of the clergy, whether Protestant or Catholic. Following the lead of $\mathrm{G}$. Oestreich, more recent studies have used local secular officials to demonstrate how intermittent the extension of early modern state authority was in Europe during the sixteenth and seventeenth centuries. ${ }^{8}$

This brief characterization of current research demonstrates how necessary it is to test the results of research on the development of "the early modern state" by looking at its mediators at the local level. This corresponds to a general trend in research that has begun to reconsider the criteria for evaluating the history of the early modern period. ${ }^{9}$ The question guiding research during the 1970s, concerning the degree of modernity within the social order, was undeniably a reflection of the times. ${ }^{10}$ This criticism, however, is by no means the same as the assertion that everything that cannot be fit into the dominant lines of development is the "better tradition." 11 This position is as clearly marked by its age as was the exaggerated emphasis on modernization. I believe that the diversity of early modern reality can be better understood by assuming the existence of two cultures that marked the period through their mutual entanglement rather than their divisive separation. ${ }^{12}$

Against this background, the following essay will sketch the current state and

idem, "Obrigkeitskritik im Luthertum? Anlässe und Rechtfertigungsmuster im ausgehenden 16. und im 17.Jahrhundert," in Querdenken: Dissens und Toleranz im Wandel der Geschichte. Festschrift zum 65. Geburtstag von H. R. Guggisberg, ed. M. Erbe et al. (Mannheim, 1996), 253-70.

8. Cf. the stimulating essay by U. Rublack, "Frühneuzeitliche Staatlichkeit und lokale Herrschaftspraxis in Württemberg," Zeitchrift für Historische Forschung [henceforth ZHF] 24 (1997): $347-76$, which uses regional examples in its discussion of the extensive current debate over the chances that governments would succeed in their efforts at centralization. Even for BrandenburgPrussia, the prime example of "disziplinierender Herrschaft von oben," one sees a "Wirkungsschwäche des ... Ediktenstaates"; see W. Neugebauer, "Brandenburg im absolutistischen Staat: Das 17. und 18. Jahrhundert," in Brandenburgische Geschichte, ed. W. Ribbe and I. Materna (Berlin, 1994), 291-394, here at 359. Cf the recent idiosyncratic but stimulating interpretation of J. Schlumbohm, "Gesetze, die nicht durchgesetzt werden-ein Strukturmerkmal des frühneuzeitlichen Staates?" Geschichte und Gegenwart [henceforth GuG] 23 (1997): 647-63.

9. For a discussion of the character of the early Reformation, see B. Moeiler, ed., Reformation als Umbruch; on the character of " absolutism," R. G. Asch and H. Duchhardt, eds., Der Absolutismus-ein Mythos? Strukturwandel monarchischer Herrschaft in West-und Mitteleuropa (ca. 15501700) (Cologne, 1996), including a historiographical introduction by the editors.

10. Cf. especially Th. Mergel, "Geht es weiterhin voran? Die Modernisierungstheorie auf dem Weg zu einer Theorie der Moderne," in Geschichte zuischen Kultur und Gesellschaft: Beiträge zur Theoriedebatte, ed. idem and Th. Welskopp (Munich, 1997), 203-32, esp. 207-14; W. Reinhard, "Sozialdisziplinierung-Konfessionalisierung-Modernisierung: Ein historiographischer Diskurs," in Die Frühe Neuzeit in der Geschichtswissenschaft: Forschungstendenzen und Forschungsergebnisse, ed. N. Boskovska-Leinegruber (Paderborn, 1997), 39-55.

11. This problem, for example, has not yet been resolved satisfactorily within the debate on the forms of "resistance" in the early modern period; cf. L. Schorn-Schütte, "Obrigkeitskritik: Überlegungen zu Konfliktlösungsmodellen im Alten Reich des 16./17. Jahrhunderts, in Strukturen des politischen Denkens im Europa der frühen Neuzeit, ed. idem (Munich, 1999).

12. See similar observations concerning the Middle Ages by O. G. Oexle, "“'Die Statik ist ein 
future tasks of research on the clergy in sixteenth- and seventeenth-century Europe, although it makes no claim to completeness. It is presented from the point of view of a secular historian who regards the pastors and priests as officials with duties and claims to act in this world. Thus the object of research is the secular function of the clergy. This function cannot, however, be separated from the clergy's self-perception. For this reason it is necessary, despite the methodological difficulties, to examine the connection between how others understood clerical office and how the clergy understood it, when making comparisons between confessions and with secular fellow officeholders. The first part of this essay discusses the possibility of linking a structural analysis with those approaches that focus on the values, norms, and experiences that shaped the actions of this social group, a topic that has particular relevance for those doing research on the clergy. The second part will sketch aspects of a comparative collective biography that includes the social integration of the clergy, their economic situation and their standards of education, which will then be used to place the conflicts between magistrate, parishioners, and officials hinted at above in their social and political context. Finally, the third section will compare across confessions how the clergy perceived themselves and their office. This section is not limited to confession-specific ideals but is equally concerned with how these ideals were "tested" in cases of conflict, i.e., in disputes with the congregation and/or the secular authority. This will bring us back to our earlier question concerning the criteria for evaluating the early modern social order and its norms.

\section{Discussion of Methodology}

The rich tradition of Pfarrhausliteratur was exclusively Protestant and generally took the form of biographies. Since the 1960s, the tools of historical sociology have increased our knowledge considerably by adding methodological breadth, demonstrated by concentrated efforts to develop a social profile of the clergy of both confessions. Extensive research on the social origin of the Lutheran clergy after the Reformation on the one hand has demonstrated their social incorporation into the urban and/or territorial bourgeoisie, and on the other hand has weakened the thesis of the constant self-recruitment of the clergy. ${ }^{13}$ On the Catholic side, similar research exists but focuses almost exclusively on the higher clergy; we lack comparable social-historical studies, in the strict sense of the word, especially for the secular and regular clergy who bore the responsibility for pastoral care. This is due above all to the problem of sources.

Grundzug des mittelalterlichen Bewusstseins': Die Wahrnehmung sozialen Wandels im Denken des Mittelalters und das Problem ihrer Deutung," in Sozialer Wandel im Mittelalter: Wahrnehmungsformen, Erklärungsmuster, Regelungsmechanismen, ed. J. Miethke and K. Schreiner (Sigmaringen, 1994), 45-72.

13. See Schorn-Schütte, Evangelische Geistlichkeit, 84-151. 
Since the 1970 s German historians have developed a very fruitful line of research on the Catholic higher clergy: the historical analysis of networks. ${ }^{1+}$ Their examination of the four dominant types of social group formation (familial relationship, regional affiliation, friendship, patronage) has shown that certain types of networks could aid the development of political structures that served as alternatives to the early modern state by forming institutions such as the ecclesiastical state. This type of network analysis presupposes an excellent collection of source documents, which are frequently lacking in the case of the secular and regular clergy who exercised pastoral care at the local level. Socialhistorical research that concentrates on these groups as mediators (at the local level) as characterized above can therefore only make limited use of this approach. Our insight into the significance of regional affiliation and of ties established within educational institutions, which can be quantitatively analyzed, has provided social-historical research on clerical elites with greater knowledge about the institutionalized exercise of power at the middle level. ${ }^{15}$

From a strictly social-historical perspective, much work still needs to be done particularly in the area of the Catholic secular and regular clergy. Despite these deficiencies, some studies since the late 1980s have turned away from a structural approach toward an examination of the activities of the clergy and their families. To defend this change of direction, historians have argued that we lose an understanding of historical reality by neglecting the "analysis of cultural patterns of action, life circumstances, and group culture." ${ }^{16}$ This argument, clearly influenced by cultural history, is by no means restricted to research on the clergy. Rather the discussion concerning the necessity of a broadening and/or reformulation of social-historical writing has stamped German historiography since the late 1980 s and extends to characterizing history as the study of historical culture. ${ }^{17}$

These approaches are without doubt stimulating for research on the history

14. This concept was formulated for German-speaking historians by W. Reinhard, Freunde und Kreaturen, "Verflechtung" als Konzept zur Erforshung historischer Fïhrungsgruppen: Römische Oligarchie um 1600 (Munich, 1979); cf. most recently idem, "Amici e Creature: Politische Mikrogeschichte der römischen Kurie im 17. Jahrhundert," Quellen und Forschungen aus italienischen Archiven und Bibliotheken 76 (1996): 308-34.

15. It is not possible to list all the literature on this topic, but for further references see SchornSchütte, Evangelische Geistlichkeit, 159-226; idem, 'Zwischen 'Amt' und 'Beruf': Der Prediger als Wächter, 'Seelenhirt' oder Volkslehrer: Evangelische Geistlichkeit im Alten Reich und in der schweizerischen Eidgenossenschaft im 18. Jahrhundert," in Evangelische Pfarrer: Zur sozialen und politischen Rolle einer burgerlichen Gruppe in der deutschen Gesellschaft des 18. bis 20. Jahrhunderts, ed. idem and W. Sparn (Stuttgart, 1997), 1-35; J. Wahl, "Karriere, Kinder und Konflikte: Lebensplanung und Alltagserfahrung württembergischer Pfarrfamilien im 17. Jahrhundert," (Ph.D. diss., Universität Tübingen, 1995, 67ff.; Ch. Weber, Senatus Divinus, Verborgene Strukturen im Kardinalskollegium der Frühen Neuzeit (Frankfurt am Main, 1996).

16. R. van Dülmen, "Vorbemerkung," in idem, ed., Arbeit, Frömmigkeit und Eigensinn (Frankfurt am Main, 1990), 7.

17. For a summary of the debate and the state of research, see W. Hardtwig and H. U. Wehler, 
of clergy, for they open a helpful path of research on the problem discussed above of the relationship between the internal and external view of clerical office. Ground-breaking studies have examined how the clergy perceived themselves and their office and include fruitful interconfessional comparisons. The numerous extant collections of printed sermons from both Catholics and Protestants from every historical period serve as sources for these studies. ${ }^{18}$ Statements of the clergy's views of themselves, as well as of the parishioners' views of their pastors, are equally well attested in archival documents describing first of all conflicts between pastor and parishioners, secondly between pastor and magistrate, and thirdly among the pastors themselves." ${ }^{19}$ The methodological question still remains whether we can make generalizations on the basis of such case studies. To begin with, the accidents of historical survival increase the risk of characterizing as a specific feature of early modern reality what was actually an exceptional case. Moreover, the understanding of the values and norms of the early modern period is so bound to the deciphering of symbolic actions and/or language that, despite all the support of ancillary disciplines (anthropology, folklore, etc.), a "remnant of the foreign" persists. Historical analysis must therefore hold on to both paths of knowledge, which act as mutual constraints, and try to determine, and thus to explain, the typical form of mental disposition, of social activity, and of institutional structures. The interconnections between these areas were precisely described in discussions of the social construction of knowledge in the late 1960s: mental dispositions arise in connection with social activity, which can in turn be modified or reestablished by attitudes, standards, and norms, resulting in visible changes in political, social, and institutional structures. ${ }^{20}$ From the viewpoint of systems theory,

eds., Kulturgeschichte heute, (Göttingen, 1996), as well as Th. Welskopp, "Die Sozialgeschichte der Väter: Grenzen und Perspektiven der historischen Sozialwissenshaft," in GuG 24 (1998): 173-98.

18. Using these sources R. Dürr has presented the first studies of the Catholic pastoral clergy within the research project mentioned above; of. her "“. . . Die macht und Gewalt der Priester aber ist ohne Schrancken . . .Z Zum Selbstverständnis katholischer Seelsorgegeistlichkeit im 17. und 18. Jahrhundert," in Hausvater, Priester, Kastraten: Zur Konstruktion von Männlichkeit in Spätmittelalter und Frïher Neuzeit ed. M. Dinges (Göttingen) 1999; R. Dür "Images of the Priesthood: An Analysis of Catholic Sermons from the Late Seventeenth Century" in this issue. Cf. the self-image of evangelical university theologians expressed in their sermons as examined by S. Holtz, Theologie und Alltag: Lehre und Leben in den Predigten der Tübinger Theologen 1550-1750 (Tübingen, 1993).

19. Cf. at length Schorn-Schütte, Evangelische Geistlichkeit, 390-452; N. Haag, Predigt und Gesellschaft: Die lutherische Orthodoxie in Ulm 1640-1740 (Mainz, 1992), 185-216; H.-Chr. Rublack, "Der wohlgeplagte Priester: Vom Selbstverständnis lutherischer Geistlichkeit im Zeitalter der Orthodoxie," ZHF 16 (1989): 1-30. For the area of Brandenburg, J. Peters, "Wilsnack nach dem Wunderblut-Nachreformatorisches Kirchenleben in einer märkischen Mediatstadt," Jahrbuch für Berlin-Brandenburgische Kirchengeschichte 61 (1977): 124-50. For the Catholic clergy, see R. Beck, "Der Pfarrer und das Dorf: Konformismus und Eigensinn im katholischen Bayern des 17./18. Jahrhunderts, in Armut, Liebe, Ehre: Studien zur historischen Kulturforschung, ed. R. van Dülmen (Frankfurt am Main, 1988), 107-43.

20. Cf. P. L. Berger and Th. Luckmann, Die gesellschaftliche Konstruktion der Wirklichkeit, 1st ed. (Frankfurt am Main 1969, the German translation of the 1966 American edition), third (paper) ed. 
moreover, social interaction is characterized as actions by individuals. Because actions result from the process of social communication, they must also be described in the form of situational analyses and functional attributions; they cannot be derived from the "meaning" surmised from an association of norms and interpretations, for in the final analysis this is a component of individual biography that is not accessible to us. ${ }^{21}$

For the historian, the above-described meshing of structures and actions and/or experiences is most easily approached through the written word; as a social group the clergy, regardless of confession, are particularly well-suited to such research questions. In their self-perceptions and in their perceptions of office they are the learned administrators of the word, although for Catholics the sacral function remained in the forefront. The analysis of perceptions of office and of self provides a theoretically-based entrance to the relationship between clerical speech and clerical actions "in the world," which also demonstrates the political aspects of their activities. If one agrees with $Q$. Skinner and J. Pocock that political theory should be understood as an answer to and an attack on socially-operative paradigms that can describe, question, or legitimate the authority and value structures of the social order, ${ }^{22}$ then the theologicallybased order of values that rests on the religious word can be conceived of as the "political-theological" vocabulary of a community that extends beyond individual validity to allow statements on the value and norm structure of the contemporary society. Thus the analysis of clerical perceptions of office and of self proves to be a previously underappreciated point of access to an analysis of the relationship between church and world in the early modern period. ${ }^{23}$ This can in no way be seen as a straight path to an ever more comprehensive secularization, as is apparent from the rediscovery of the normative function of piety and confessional ties in the early modern period. The simple equation of "pious"

(Frankfurt am Main, 1993), 1ff. This approach has only recently been applied in German historical scholarship; cf. O. G. Oexle, "Deutungsschemata der sozialen Wirklichkeit im" frühen und hohen Mittelalter," in Mentalitaten im Mittelalter: Methodische und inhaltliche Probleme, ed. F. Graus (Sigmaringen, 1987), 65-117; F. M. Kuhlemann, "Theoretische und methodische Überlegungen am Beispiel der Religion im 19. und 20. Jahrhundert," in Kulturgeschichte heute, ed. Hardtwig and Wehler, 182-211; Schorn-Schüte, "Drei-Stände-Lehre." The discussion with J. R. Searle, Die Konstruktion der gesellschaftlichen Wirklichkeit: Zur Ontologie sozialer Tatsachen (Hamburg, 1997; German translation of the 1995 English edition) belongs in this context.

21. Cf. R. Schlögl, “'Aufgeklärter Unglaube' oder 'mentale Säkularisierung'? Die Frömmigkeit katholischer Stadtbürger in systemtheoretischer Hinsicht (ca. 1700-1840)," in Geschichte zurischen Kultur und Gesellschaft, ed. Mergel and Welskopp, 99-100. The argument from systems theory is here acceptable.

22. Cf. the references in n. 6 .

23. For an attempt to apply this approach to political thought as a form of political action in the sixteenth and seventeenth centuries, L. Schorn-Schütte, “'Politica Christiana' und 'Ratio Status': Überlegungen zu Alternativen politischen Denkens in der Frühen Neuzeit, in Strikturen des politischen Denkens im Europa des 16. und 17. Jahrhunderts, ed. idem (Munich, forthcoming). 
and "backward" has lost its explanatory power. The criteria for characterizing historical change must therefore be reconsidered.

\section{Aspects of a Social Biography of the Clergy}

International research on the structure and duties of the European clergy from the mid-sixteenth century is multifaceted but goes in many unevenly developed directions. It is therefore extremely difficult to give a survey of comparative research. Clearly, everyone agrees that there is something like a social or collective biography of the clergy, ${ }^{2+}$ since the studies concentrating on different countries and in part even on comparisons between confessions agree for the most part on the value of their social-statistical approach. There is a strict differentiation made within the Catholic clergy: research on the parish clergy, ${ }^{25}$ the lower secular and regular clergy at the congregational level who assumed the responsibility for pastoral care, is seen as a distinct task. ${ }^{26}$ In general, a collective biography has four aspects used by researchers:

1. Social and regional origin of the clergy, social integration in the sense of network analysis.

2. Training and educational level of the clergy, access to clerical office, economic situation.

3. Standards for clerical office: conduct and lifestyle, clerical duties.

4. Self-perception and perception of others: clerical self-understanding, expectations of their parishioners, expectations of secular and ecclesiastical government.

Alongside the differences between the confessions that occur particularly with regard to network analysis, national differences within the same confession are also noteworthy. Similarities bridging confessional and national differences also exist in self-perception and the perception of others. The material dependence of the clergy on one hand, their religious claims on the other, and the expectations of congregation and magistrate as a third aspect were components

24. "Wahl, "Karriere, Kinder und Konflikte," $58 \mathrm{f}$., emphasizes that the social origins of the clergy are not simply statistical figures but also allow us to make "Aussagen über die historisch wandelbaren Wahrnehmungsmuster der Gesellschaft gegenüber dem Pfarramt." In fact, as D. Gugerli has pointed out, fathers' marriage and career strategies for their sons had a long-term impact already in the early modern period, Zwischen Pfrund und Predigt: Die protestantische Pfarfamilie atf der Zürcher Landschaft im ansgehenden 18. Jahrhundert (Zurich, 1988), 141-96. This applies to all other social groups as well.

25. On this term, see J. Bergin, "Between Estate and Profession: The Catholic Parish Clergy of Early Modern Western Europe," in Social Orders and Social Classes in Europe since 1500: Studies in Social Stratification, ed. M. L. Bush (London, 1992), 6-85.

26. Cf. D. Julia, "Il prete," in L'uomo dell'lluminismo, ed. M. Vovelle (Rome, 1992), 399-443; A. Turchini, "La nascità del sacerdozio come professione," in Disciplina dell'anima, disciplina del corpo e disciplina dell società tra medioevo ed età moderna, ed. P. Prodi (Bologna, 1994), 225-56; C. Fantappié, "Istituzioni ecclesiastiche e istruzione secondaria nell'Italia moderna: i seminari-collegi vescovili," Jahrbuch des italienisch-deutschen historischen Instituts in Trient 15 (1989): 189-240. 
of continuing conflict that offer far-reaching insights into the structures of early modern society and their potential for change. The following section outlines some preliminary conclusions.

\section{Social/Regional Origin and Integration}

1. Comparative studies of the social origin of Protestant and Catholic clergy in the Old Empire have led to a fundamental revision of the traditional picture of the peasant origin of Catholic priests. ${ }^{27}$ Despite inadequate sources for both confessions in the late sixteenth and early seventeenth centuries, it can be established that just like Protestant pastors of the second and third generations, apparently the majority of Catholic priests responsible for pastoral care came from the urban or territorial bourgeoisie..$^{28}$ Data from Catholic areas make clear that social status must be seen in connection with the introduction of ordination titles at the end of the sixteenth or early seventeenth centuries. ${ }^{29}$ In this way the entrance to clerical office was barred for the great majority of poor, independent peasants but remained open for prosperous urban burghers, for wealthier peasants, as well as for the class of territorial officials

27. This conception was clearly shaped by the work of A. Neher, Die katholiscle und evangelische Geistlichkeit Wiirttembergs 1813-1901 (Ravensberg, 1904), esp. 22f. There were also studies on the social origin of clergy in religious orders, e.g., Krausen, "Die Zusammensetzung der bayerischen Prämonstratenserkonvente 1690-1803," Historisches Jahrbuch 86 (1966): 157-66.

28. This assumption is based on numerous regional studies of the parish clergy in the Old Empire as well as on the research carried out by the above-mentioned research project financed by the VW-Stiftung. It rests on data concerning Catholic and Protestant parish clergy in the Old Empire, the Swiss Confederation, and the Polish aristocratic republic. The studies which present information on the social origins of both secular and regular clergy who were responsible for pastoral care are A. Hahn, Die Rezeption des tridentinischen Pfarrerideals im westtrierischen Pfarklerus des 16. und 17. Jahrhunderts (Luxembourg, 1974), 28-32; G. Knetsch, "Die Geistlichen in Frickenhausen/ M.: Grundlagen und Personen," in Kirche und lädliche Gesellschaft in Mainfranken von der Reformation bis zur netuesten Zeit, ed. K. W. Wittstadt (Würzburg, 1988), 214; Th. P. Becker, Konfessionalisierung in Kurköln: Untersuchungen zur Durchsetzung der katholischen Reform in den Dekanaten Ahrgau und Bonn anhand von Visitationsprotokollen 1583-1761 (Bonn, 1989), 77-82; W. Enderle, Konfessionsbildung und Ratsregiment in der katholischen Reichsstadt Überlingen (1500-1618) im Kontext der Reformationsgeschichte der oberschwäbischen Reichstadte (Stuttgart, 1990), 203-74; W. Zimmermann, Rekatholisierung, Konfessionalisienning und Ratsregiment: Der Prozess des politischen und religiosen Wandels in der österreichischen Stadt Konstanz 1548-1637 (Sigmaringen, 1994), 264-75; see, also Schorn-Schütte, "Christian Clergy." Surprisingly, two important recent works concerned with the interpretation of Catholic confessionalization contain only cursory references to the social origin of the clergy, but they also confirm this thesis; cf. W. Freitag, Pfarrer, Kirche und landliche Gemeinschaft: Das Dekanat Vechta 1400-1803 (Bielefeld, 1998); A. Holzem, "Religion und Lebensformen: Katholische Konfessionalisierung im Sendgericht des Fürstbistums Münster 1570-1800," (Habil. MS, Universität Münster, 1996). On the basis of his examination of the eleven village churches in the area he studied, Freitag established that the pastors were mostly sons of the middling classes in small territorial cities or (at least in the sixteenth and early seventeenth centuries) sons of village pastors (!) or of prosperous peasants.

29. Becker, Konfessionalisierung, 92-93, with reference to E. Hegel, Geschichte des Erzbistums Köln (Cologne, 1979), 4:170. In order to be ordained, one had to have proof of sufficient economic 
(court, administration, university). ${ }^{30}$ The predominance of more prosperous and/or academically trained burghers as a recruiting field for members of the Jesuit order fits well into this picture. ${ }^{31}$

These observations apply to France and Italy as well. With regard to France, J. Bergin has stated, "One of the most significant features of the French Counter-Reformation parish clergy is how large a proportion of it was drawn from the bourgeoisie of town and country." ${ }^{32}$ In the mid-seventeenth century the bourgeoisie comprised up to 85 percent of the parish pastors, just as in the Old Empire, social groups below the urban and territorial bourgeoisie were excluded from entrance to clerical office. ${ }^{33}$ The proportion of the aristocracy among the parish clergy corresponded almost exactly to their proportion among the general populace. The bourgeois dominance that is observed in France from the late sixteenth century on seems to be connected in part to economic considerations. On the basis of its exemption from taxation, the pastoral clergy had a privileged position in an economically overburdened society. ${ }^{3+}$ In addition, the French Catholic Church contributed to social change through its persistent efforts to improve the standards of education. We will come back to this point.

The developments in Italy are in many ways similar to France. Various recent studies have shown that members of the urban elite chose clerical office for economic reasons. From the mid-seventeenth century this development was strengthened by the fact that the episcopal seminary-colleges founded for the training of future clergy were opened to the economically powerful urban bourgeoisie as well as to interested aristocratic laymen. ${ }^{35}$ The majority of the students who came from these social groups remained laymen, but some found their way into clerical office.

A glance at the regional origin of the Catholic pastoral clergy in the Old Empire confirms the findings concerning social origins. From the beginning of the seventeenth century the pastoral clergy in the countryside in all but

support (an ordination title). For clergy in Luxembourg, the ordination title required the equivalent of 50 Reichstaler. The title generally was based on the yield of fields and pastures, according to Hahn, Die Rezeption des tridentinischen Pfarrerideals, 31, n. 111.

30. Becker, Konfessionalisierung, 81; Knetsch, "Geistlichen," 136; Zimmermann, Rekatholisienung, 272-75. Hahn also refers to the existing proportion of the nobility and the peasant population, Rezeption des tridentinischen Pfarrerideals, 30-31.

31. Cf. R. Po-chia Hsia, Social Discipline in the Reformation: Central Europe 1550-1750 (London, 1989), 48-50.

32. Bergin, "Between Estate," 76-77.

33. Bergin, "Between Estate," also points out that in certain French dioceses opportunities existed for the sons of prosperous peasants. The very general statement of U. Im Hof, Das Europa der Aufklärung (Munich, 1993), 42-43, that the lower clergy were often of peasant background, needs to be revised.

34. Bergin, "Between Estate," 77-78.

35. Cf. Fantappié, "Istituzioni ecclesiastiche"; D. Julia, "Il prete." 
exceptional cases came from the territory or even from the parish itself. The example of the diocese of Würzburg ${ }^{36}$ shows that they came mostly from neighboring towns, often the seat of court and territorial administration or defensive centers. This pattern of regional origin applies as well to those ecclesiastical territories, such as the prince-bishopric of Münster, in which Tridentine reforms, e.g., the requirement that pastors reside in their parish, were implemented only with great effort. In fact, the most confessionally reliable candidates, who were necessary for the stabilization of a Catholicism renewed by Trent, came from distant regions, ${ }^{37}$ but most of them came from cities. Urban origin again predominated among the "native" clergy after the mid-seventeenth century. ${ }^{38}$ Thus for Catholic Germany, we can assert that on the basis of the cultural distance "between the pastor marked by his urban background and the rural milieu of the faithful ... the gulf between pastor and parishioners" grew ever wider over the course of the seventeenth century. ${ }^{39}$

Already in the seventeenth century the regional mobility of the French Catholic parish clergy was more marked than that of the pastoral clergy in the Old Empire. "1 There was a clear disparity between different church provinces, as can be determined by looking at the criteria of over- and undersupply. As a consequence, certain regions (for example, the south) were dependent on the supply of future clergy (for example from northern regions). Bergin even dares to state that the "geography of clerical recruitment" described only for the nineteenth century applied already in the seventeenth century. ${ }^{41}$ The basis for this was again primarily economic, since the extremely permeable diocesan borders allowed clergy a certain degree of mobility in search of positions. They clearly moved to areas where the highest-paying benefices could be found. This is on the one hand a sign of the clergy's regional independence and on the other evidence for the lack of supraregional qualifications for the admission to clerical office before the end of the eighteenth century.

Despite the reform decrees of the Council of Trent, and particularly in Italy, clerical office continued to be treated as a private domain which, according to private law, could be freely bestowed. This practice was made possible and even encouraged by the tremendous variety regarding patronage rights, often combined with different local privileges as well. Clerical prebends were seen by the families of their holders as one of the means by which they cared for their own

36. Cf. the map, "Herkunftsorte und Diözesangrenzen (Bistum Würzburg)" in Knetsch, "Die Geistlichen," 159.

37. Cf. the extensive discussion in Freitag, Pfarrer, Kirche und ländliche Gemeinschaft, 185-87, with Table 8 .

38. This discussion follows Freitag, Pfarrer, Kirche und ländliche Gemeinschaft, who characterizes those who originated from the surrounding area as "indigenous."

39. "Becker, Konfessionalisierung, 82.

40. On the following of. Bergin, "Between Estate," 72-74.

41. Ibid., 72 . 
members. ${ }^{42}$ There was therefore no specifically regional mobility among the pastoral clergy.

2. The social integration of the Protestant clergy has been better documented, at least from the end of the sixteenth century. ${ }^{43}$ Recent research, including my own, ${ }^{4+}$ which compares the Old Empire, the Swiss Confederation, and the Polish aristocratic republic, downplays the still accepted belief about self-recruitment to clerical office. The data presented in Table $1^{15}$ show that the urban and territorial administration played a very significant role in recruiting potential pastors and pastors' wives on the one hand and as occupational fields for their sons and sons-in-law on the other. In some regions the occupations of "artisan" or "merchant" continued to play a significant role. ${ }^{\text {th }}$ From this it is clear that the Lutheran clergy were integrated into a group that had increased tremendously in significance as non-noble instrumental agents, often with legal training, serving the territorial and urban authorities. A growing network of personal and familial relations connected these groups; if one speaks of self-recruitment at all, it must be with regard to the whole group. ${ }^{47}$ The developing trend makes clear that upward social mobility within the group of civic office holders was possible over the course of two or three generations; clerical office proved to be a Plattformberuf. ${ }^{+8}$ This relationship was even more clear for the social origin of pastors' wives. The numbers reflect the character of early modern marriage, which proved to be an important factor for the integration of the Protestant clergy: along with providing for both spouses it served (especially at the end of the sixteenth century) both social establishment and social ascent. ${ }^{49}$

42. Cf. Julia, "Il prete."

43. For German-speaking areas (including the Swiss Confederation and the three major cities in royal Prussia), fundamental source material includes the Pfarrbuicher, which over the past century and up to the present have been compiled on the basis of archival research. For extensive citations on the state of social-historical research on the Protestant clergy in the broader European context, see Schorn-Schütte, Evangelische Geistlichkeit, 31-48.

44. Cf. the references in notes $2-3$ above as well as the studies that have been produced by the above-mentioned research project taking a comparative perspective for all of Europe.

45. See the Appendix, Table 1: Comparison of the Social Origin of Protestant Clergy which is in part based on my own work, "Zwischen 'Amt' und 'Beruf'," 27, as well as on work done within the above mentioned research project (as of 2 February 1998).

46. Research on the social origin of the pastors of the university city of Rostock during the seventeenth century has sharply revised the dominent picture of self-recruitment. A third of the pastors came from the city's merchant elite, another third from the urban functional elite, and the last third came from the parsonage; see J. Strom, "Orthodoxy and Reform: The Clergy in 17th Century Rostock," (Ph.D. diss., University of Chicago, 1996) 419.

47. Wahl also reaches this conclusion for the region he examines, "Karriere," $58 \mathrm{ff}$.

48. Cf. H. Mitgau, Familienschicksal und soziale Rangordnung: Untersuchungen iber den sozialen Aufstieg und Abstieg (Leipzig, 1928); cf. also Schorn-Schütte, Evangelische Geistlichkeit, 52.

49. Documented in Schorn-Schütte, Evangelische Geistlichkeit, 493-96 (graphs for individual regions in the Old Empire). For an extensive discussion of the role of the pastor's wife see L. Schorn-Schütte, "Gefährtin' und 'Mitregentin': Zur Sozialgeschichte der evangelischen 
Developments in the Protestant cantons of the Swiss Confederation did not differ essentially from the patterns described for the territories of the Old Empire. The much-cited continuity of profession within the clergy cannot be proved for the Swiss cantons, either..$^{50}$ In some territories that have been examined, the clergy clearly showed a lesser tendency to remain in the same profession than did artisans. ${ }^{51}$ The consistently high proportion of clergy recruited from among artisans is striking.

One can no longer speak of the "platform" function of clerical office in Zurich's territory by the eighteenth century. In any case there are two developments specific to Zurich in the eighteenth century that should be noted: first, the increased attractiveness of clerical office, since Zurich's city government (unlike many urban magistrates in the Old Empire) guaranteed a secure income at a time when the economy was declining, and second, the rapid increase in those waiting for a pastorate from the mid-eighteenth century, an influx that did not begin in the Old Empire for another twenty years. ${ }^{52}$ The result of both developments was an increase in the social prestige of clerical office that made it unobtainable for social climbers.

A glance at England confirms our observations concerning the social integration of Protestant clergy on the Continent. After a period of uncertainty and instability, the new Anglican and/or Puritan clergy began to establish themselves socially at the end of the sixteenth and the early seventeenth centuries. This is revealed by the fact that future clergy now also came from the gentry, so that the chance for social ascent for the sons of yeomen, which had actually existed from the mid-sixteenth century, began to decline. ${ }^{53}$ This social integration does not mean that a new aristocratic church was created in English Protestantism. Social-historical research has shown instead that the close connection between gentry and urban bourgeoisie in England helped establish the middle social group from which academically-trained civil servants were

Pfarrfrau in der Frühen Neuzeit," in Wandel der Geschlechterbeziehungen zu Beginn der Neuzeit, ed. H. Wunder and Chr. Vanja (Frankfurt am Main, 1990), 109-53. A revised version in English translation in S. Seidel-Menchi and A. J. Schutte, eds., Space and Time in Women's Life (Kirksville, 1999); a critical discussion of my theses in Wahl, "Karriere," 202-17.

50. See Appendix, Table 2: Comparison of the Social Origin of Protestant Clergy (as of 2 February 1998).

51. See the comparison with the Old Empire but concentrating on the eighteenth century in Schorn-Schütte, "Zwischen 'Amt' und 'Beruf"," 7-9. The figures for Switzerland are based on the stimulating work of Gugerli, Zwischen Pfrund.

52. The analysis of "surplus and shortages in the Protestant pastorate since the eighteenth century" is a particularly informative means of explaining the "sponge effect" that clerical office exercised and with whose help certain social groups characterized as "bildungsferne" were able to enter the pastorate in a cyclical pattern from the middle of the eighteenth century. $\mathrm{Cf}$. the article by Titze, "Überfüllung und Mangel im evangelischen Pfarramt seit dem 18. Jahrhundert," in Evangelische Pfarrer, ed. Schorn-Schütte and Sparn, 56-76.

53. Cf. the informative overview of V. Barrie-Curien, "The English Clergy 1560-1620: Recruitment and Social Status," History of European Ideas 9 (1988): 451-63, esp. 453-54. 
recruited on the Continent; the Protestant clergy belonged to this group. In England, as in the Protestant areas of the Continent, the clerical elite belonged to this social "middle class." Anglican bishops were, for example, "sons of merchants, clothiers, tailors, yeomen, and small gentry. They succeeded in becoming the equals of the lower gentry and of urban middle classes, but never of the nobility, which they could not enter even by marriage." ${ }^{54}$ In this respect there was a significant difference from the old church.

An examination of regional and academic mobility for the Old Empire confirms these findings concerning social mobility. Of course there was a change between the late sixteenth and the early eighteenth centuries. For at least the first two generations of the Protestant clergy there is a strong movement from outside, but after the consolidation of confessional boundaries the clergy were recruited increasingly from within the territories themselves. ${ }^{55}$ On the one hand, this was a result of the development of a territorially-defined system of scholarships for theology students who were obligated to study at the territory's university. On the other hand it was the result of a system of patronage whose validity remained uncontested in Protestant territories after the Reformation, and which made the personal ties of clientage to noble, urban, or parish patrons the fundamental condition for a position. In any case it should be observed that in the larger territories even among the rural clergy a significant portion of theologians were "foreigners." Regional mobility remained the highest during the entire early modern period among those who held positions of ecclesiastical leadership (superintendents, Ober or Erste Pfarrer, deans, theology professors, etc.). ${ }^{56}$

The developments are similar for England, ${ }^{57}$ but in Switzerland there was a "begrenzte Kleinräumigkeit" from the end of the sixteenth century. ${ }^{58}$ For both the city and territory of Basel, as well as for the city and territory of Zurich, at least two-thirds of the later pastors attended either the University of Basel or the Zurich Carolinum. If supraregional contacts existed at all in the area of education, then they were only within clearly defined confessional regions. The

54. Ibid., 454 .

55. See Appendix, Table 3: Comparison of Regional Origin of Protestant Clergy which is based on the research in the above-mentioned research project (as of 2 Feb. 1998).

56. These differences are particularly obvious in Mecklenburg: the rural clergy studied exclusively in Rostock, while the pastors and the theology professors in the city of Rostock always studied at various universities outside of the territory. The practice of a Studienreise, often as companions to young noblemen, continued into the seventeenth century; cf. Strom, "Orthodoxy and Reform," 79-81 and Th. Kaufmann, Universität und hutherische Konfessionalisienng: Die Rostocker Theologieprofessoren und ihr Beitrag zur theologischen Bildung und kirchlichen Gestaltung im Herzogtum Mecklenburg zwischen 1550 and 1675 (Gütersloh, 1997), 149-50.

57. Cf. Barrie-Curien, "English Clergy," 454-55. In England during the later sixteenth and early seventeenth centuries some of this mobility can be explained by the search for better-paying positions. A similar phenomenon with regard to Catholic pastoral clergy in France has been described above.

58. Cf. for the eighteenth century, Guggerli, Zurishen Pfrund. 
"narrowly-defined society, organized by region and order, with the court and/or state at the center" ${ }^{\prime \prime 9}$ is seen clearly here, even if there were no courtly centers in the Confederation. The urban governments of the chief cities were understood by contemporaries as centers of governmental authority.

With regard to the parish, the regional ties of most of the Protestant rural clergy surely had a positive effect, for access to regional traditions of piety were easier for those who knew them from their own experience.

\section{Training and Educational Level of the Clergy: Access to Clerical Office: Economic Situation}

With the Reformation, prereformation criticism turned into, among other things, a demand for well-trained pastors. The Protestant view that the Reformation was also an educational movement is therefore correct. However, the needed reforms were not implemented in the direct and matter-of-fact fashion in which they have often been presented. Certainly over the course of the entire early modern period the ideal view of clerical office was realized in practice. But the path to this achievement was long and for both confessions followed a much more comparable route than previous research has described.(1)

For the Old Empire the comparative evaluation of visitation protocols of both confessions from the end of the sixteenth century shows a striking agreement with regard to educational level and criticism of the conduct of both Lutheran and Catholic clergy. ${ }^{61}$ This indicates that the Catholic norms that stemmed from the reform impulses of Trent largely corresponded with those that shaped the ideal image of the pastor within Lutheranism during the second third of the sixteenth century. At this time there was not a significant number of parish clergy who had completed a university education in either Catholic or in Protestant territories. ${ }^{6.2}$ In both areas there was a colorful mixture of Catholic and Protestant theological positions that were rooted in the equally mixed forms of pastoral care and parish piety. These combinations are especially clear where there were confessional changes or where two confessions tried to live with and alongside each other. ${ }^{63}$ The reform and/or

59. P. Moraw, "Aspekte und Dimensionen älterer deutscher Universitätsgeschichte," in Academia Gissensis, ed. idem and V. Press (Marburg, 1982), 1-43, esp. 35.

60. Cf. the stimulating research on England, especially R. O'Day, The English Clergy: The Emergence and Consolidation of a Profession 1558-1642 (Leicester, 1979), and more recently BarrieCurien, "The English Clergy." Also important is the work by B. Vogler, Le dergé protestant hiénan an siècle de la reforme (1555-1629) (Paris, 1976). On Protestantism in the Old Empire cf. SchornSchütte, "Christian Clergy," and idem, Evangelische Geistlichkeit.

61. Schorn-Schütte, "Christian Clergy."

62. On developments in Protestantism, see Schorn-Schütte, Evangelische Geistlichkeit; for Catholicism, cf. Holzem, "Religion und Lebensformen," 46f., and Freitag, Pfarrer, Kirche und ländliche Gemeinschaft, 81-86.

63. In his study of the prince-bishopric of Münster, Holzem states that for the late sixteenth 
institutionalization of the educational process, which started first in Protestant areas but began to affect Catholic regions as well by the beginning of the seventeenth century, had as its goal for both confessions an improvement in the level of theological knowledge and the "maintenance of clerical dignity." For both the goal of education was tied to an ethos of clerical office that prescribed a certain way of life, although this differed according to confession. In the praxis of education there were significant formal differences, but in content they did not necessarily lead to a lower level of education in Catholic areas.

1. In view of the regional variations in Protestantism and the regional variations in the implementation of the Council of Trent's decrees concerning clerical reform that have only been examined in part, ${ }^{6+1}$ I shall here simply refer to some of the paths of development to a formalized educational process in the eighteenth century. Due to the secular authority's general failure to implement the reform decrees of the council, the activities of the reform orders (including the Franciscans, and above all the Jesuits) can scarcely be overestimated. Often the Jesuit order succeeded in establishing seminaries for priests, where the initiatives of the territorial ruler failed. By means of these seminaries, the abuses associated with a lack of clerical education and sacral schooling would be counteracted among future pastoral clergy, although in this they were only partially successful ${ }^{65}$ For this reason the period until about 1650 must be considered as a transitional phase for the Catholic clergy, who were characterized by considerable institutional and individual weaknesses in the level of education, conception of office, and conduct both in office and in lifestyle. The Tridentine Catholic reform movement found in the image of the "good shepherd" (pastor bonus) a new approach oriented toward the patristic ideal of the bishop, according to which the pastor was to be "leader of the congregation, proclaimer of God's word, and dispenser of the sacraments." ${ }^{66}$ These duties were normative for the Jesuit concept of education; the correct exercise of clerical actions and blameless morals became the focus of Jesuit education. ${ }^{67}$ Corresponding to this was the institutionalization of education, which has been aptly termed a

century, "Es ist nicht anzunehmen, dass lutherische visitatoren oder calvinistische Kirchenräte das Wissen, die Überzeugungen und die Amtsfuhrung dieser Geistlichen als rundheraus in ihrem Sinne empfunden hätten," "Religion und Lebensformen," 53.

64. On the process of education in Protestant areas, see Schorn-Schütte, Evangelische Geistlichleeit, for Catholic areas see the two recent case studies by Freitag, Pfarrer, Kirche und ländliche Gemeinschaft, and Holzem, "Religion und Lebensformen," with references to older literature.

65. Despite many counterexamples, Hahn's statement that "der Pfarrklerus des 16. und des 17. Jahrhunderts erhielt seine theologische Ausbildung insgesamt weder in einem der vom Konzil vorgesehenen Seminare noch in der herkömmlichen Art, auf der Universität" still points to the core problem up to the mid-seventeenth century; Rezeption des tridentinischen Pfarrerideals, 115.

66. See the corresponding characterization in Holzem, "Religion und Lebensformen," 238-39 and Freitag, Pfarrer, Kirche and ländliche Gemeinschaft, 160f., who describes this as an "Anforderungsprofile"; cf. also the essays by Dürr, "... Die Macht und Gewalt," and in this issue.

67. Holzem, "Religion und Lebensformen," 239-40, citing H. Jedin, "Das Leitbild des 
Verkirchlichung of the gymnasia and universities ${ }^{68}$ In accordance with the ratio studionum, the studia inferiora were taught together with Catholic doctrine and confessionally-specific forms of piety in the five classes of all Jesuit gymnasia. In most cases, philosophical-theological colleges were associated with the gymnasia that served for the further training of future priests. The subjects taught there comprised the studia superioria, i.e., the fundamentals of theology, of the Old and New Testaments and of the church fathers. ${ }^{69}$ Graduates could study at either a nearby arts faculty or at a seminary for priests. The seminary in Münster/Westphalia, for example, could accept up to eighteen seminarians whose training would last six years; the language of conversation and instruction was Latin. It is particularly noteworthy that all seminarians had to practice giving sermons, which ensured that their training was practical. After four years the candidates for the priesthood were ordained and had to attend the Jesuits' catechetical classes held in the city. Students had to be eighteen years of age to enter the seminary, so that an ordained priest would be at least twenty-four when he received a parish.

On the basis of recent regional studies, it is possible to assess how well the process of education was put into practice. The cases of the prince-bishoprics of Münster and Osnabrück show that the qualifications of future pastoral clergy rose slowly but steadily after the first third of the seventeenth century. ${ }^{71}$ Although the negative assessment of the area west of Trier during the sixteenth century ${ }^{71}$ can also be applied to the two northern German bishoprics, the picture becomes more nuanced for the post-Tridentine pastoral clergy. Thus, for example, a good half of the clergy in one north German deanery can be shown to have attended a nearby Tridentine gymnasium. Most of the later pastoral clergy also received the second half of this training, attendance at a regional

Priesters nach dem Tridentinum und dem Vaticanum II," Theologie und Glauben 50 (1970): 102-24, esp. 111.

68. Cf. A. Schindling," Schulen und Universitäten im 16. und 17. Jahrhundert: Zehn Thesen zu Bildungsexpansion, Laienbildung und Konfessionalisierung nach der Reformation," in Ecclesia militans: Studien zur Konzilien- und Reformationsgeschichte. Remigins Bäumer zum 70. Geburtstag, ed. W. Brandmüller, vol. 2, Zur Reformationsgeschichte (Paderborn, 1988), 561-70; Freitag, Pfarrer, Kirche und landliche Gemeinschaft, 163. The cathedral school in Münster was headed by the Jesuits from 1588 ; the school in Osnabriick from 1623. It seems unlikely to me that this transformed the cathedral schools into "jesuitische Kaderschmieden," because the Jesuits were concerned with implementing the decrees of the Council of Trent, not yet their own special interests.

69. For the Jesuit course of study, see $\mathrm{K}$. Hengst, Jestiten an Universitaten und Jesuitemuniversitaten (Munich, 1981), 70f. H. Dickerhof surveys the Catholic schools in "Die katholischen Gelehrtenschulen des konfessionellen Zeitalters im heiligen Römischen Reich," Die katholische Konfessionalisierung, ed. W. Reinhard and H. Schilling (Gütersloh, 1995), 348-70.

70. The following is based on the two above-mentioned studies by Freitag and Holzem.

71. Hahn summarizes his results for the early seventeenth century, "Mit Händen zu greifen ist der Mangel an geistigem und geistlichem Format dort, wo Leben und Tätigkeit eines Pfarrers sich merklich weit von dem entfernte was man selbst von einem Laien erwartete," Rezeption des tridentinischen Pfarrerideals, 123. 
Jesuit college with its binding cura-examination. ${ }^{72}$ There were still only a few clergy who had received an academic degree at a university; as a rule they studied at a Jesuit college for four years. They thereby received "uniform specialized professional training", $;^{73}$ unlike the situation in the late Middle Ages and also unlike that of contemporary Protestantism, a university education culminating in a degree no longer belonged to the educational reality of the Catholic clergy.

Nevertheless it is still questionable whether one can speak of "centralized management." ${ }^{7+}$ To be sure, within the small region examined here, from the mid-seventeenth century all those presented to a parish position had been ordained as priests, which only a bishop or suffragan could administer (after the candidate had passed the above-mentioned examination). This did not lead to an automatic appointment to a parish, since, as a consequence of the broadlydistributed patronage rights, all other church patrons had the right to participate in the appointment process up until the end of the Old Empire. ${ }^{75}$

This raises the question of the "path to office," whose characteristics determined status within the classification of early modern professions. The Tridentine seminary decree required the bishop to establish a seminary but did not oblige the candidate for ordination to complete the course of education there. The slow establishment of seminaries in the entire empire limited the general acceptance of qualifications for the priesthood, which could not be raised by the Jesuit educational institutions alone. The fact that in the princebishopric of Münster "the reception of priestly ordination was linked to the knowledge attained" 76 is, in view of present research, only evidence that the demands for higher qualifications could be treated very differently in various regions of the empire. Until the end of the Old Empire, the combination of formal qualifications with clientage and/or familial connections so characteristic of the early modern period could not be abandoned; older European constitutional principles were only gradually linked with those that led to a change in tradition.

During the sixteenth century there were frequent cases in which Catholic parish clergy tried to provide for their sons. This familial connection disappeared with the gradual implementation of Tridentine clerical reform. The "pastor's sense of family" (Pfarffamiliensinn) was replaced by the pastor's provision for nephews and great-nephews. ${ }^{77}$ The change in elites that resulted can

72. See Freitag, Pfarrer, Kirche und ländliche Gemeinschaft, 187-90: "Damit ist evident, dass im Gegensatz zum Spätmittelalter und dem 16. Jahrhundert das Studium, und zwar ein theologisches, Verpflichtung und geübte Praxis war" (p. 189).

73. Ibid.

74. Ibid., 190.

75. For more precise details cf. Holzem, "Religion und Lebensformen," $246 f f$.

76. Freitag, Pfarrer, Kirche tmd landliche Genteinschaft, 191.

77. Ibid., Table 11: Klerikale Verwandtschaft, 198. 
be seen in the first half of the seventeenth century, while the transformed network of familial relations was stabilized in the eighteenth century.

Finally, the path to a pastorate did not occur without preliminary stages related to office. The function of the chaplain as an assistant to the officeholder made this position an obvious first step, and at least in the prince-bishopric of Münster it played such a role. Whoever received a pastorate remained there as a rule until the end of his career or life. There was no retirement, although a priest could receive an assistant who could lighten the work of an aging pastor, and at the same time have some hope of succeeding him.

2. Because of their focus on preaching, the central concern for Protestants was improvement in the clergy's theological knowledge. In the imperial cities as well as in Protestant territories, the standards would be raised, it was hoped, through the creation of a unified system of Latin schools, cloister- or chapter schools (as, for example, in Braunschweig-Wolfenbüttel or in Württemberg) and universities. Elementary Latin, hymns, and Luther's catechism were taught in the Latin schools. In some territories (Braunschweig-Wolfenbüttel, Württemberg, Hesse) a system of scholarships was funded from church property to support gifted but poor students who were intended to meet the need for future clergy. The success of these systems can be demonstrated very clearly in the principality of Braunschweig. ${ }^{78}$

Already in the 1580 s these measures began to have an impact. Of the seventy-six clergy who entered the service of the principality between 1585 and 1630,80 percent had studied at the principality's university. Within two generations the goal of a university education, at least in the arts, had been formally attained for the future clergy of this Protestant territory. This does not mean, however, that all beginning pastors had a more thorough education than did the first generation of Lutheran clergy. Despite the stipulations of the church ordinance of $1569,{ }^{79}$ evidence of having completed a university education, even within the arts faculty, was not necessary for appointment to a parish position. Studies on the educational level of the clergy in the principality of Braunschweig-Wolfenbüttel between 1589 and 1630 show a clear educational disparity between the ecclesiastical leadership and the ordinary clergy; this is confirmed by research on other areas. ${ }^{81}$ Duration of study and academic degrees are good indicators; according to these, the great majority of the ordinary Protestant clergy had attended a university but did not necessarily attend

78. For details and further literature see Schorn-Schütte, Evangelische Geistlichkeit, chap. 3.

79. Reprinted in E. Sehlung, ed., Die evangelischen Kirchenordnungen des 16. Jalrhunderts, vol. 6: Niedersachsen, Part 1, Die welfischen Lande, vol. 1 of $\mathrm{pt}$ 1, Die Fürstentïner Wolfenbüttel und Lüneburg mit den Städten Bratuschweig und Lïneburg (Tübingen, 1955), 83-280, esp. 182f.

80. For Mecklenburg, cf. Strom, "Orthodoxy and Reform," 77-79. Kaufmann's observations apply to the theology professors and therefore confirm the basic tendency sketched here, Universitit und hitherische Konfessionalisiening, 145-51. 
lectures in the theological faculty and could not produce any certification of their studies within the arts faculty. ${ }^{81}$

Despite this latitude regarding university qualifications, by the mid-seventeenth century there were clear rules for appointment to a parish: the church ordinances of the late sixteenth century had a normative effect. After an average of seven years at a preparatory school, the typical clergyman began study in an arts faculty at about age twenty and finished between the ages of twentythree and twenty-four. Studies of the post-university age structure in the first half of the seventeenth century show for the average clergyman a longer period of time in nonecclesiastical posts such as that of private tutor. This period was frequently followed by appointment to a first church office as rector, corrector, or adjunct pastor. Another several years passed before appointment to the first parish position, so that for the sixteenth and seventeenth centuries (to use the case study of Braunschweig-Wolfenbüttel) the average age of a new pastor was 33.4 years. ${ }^{{ }^{82}}$ For the later seventeenth and eighteenth centuries detailed analyses have shown that there was a cycle of over- and undersupply of pastors (at least within Protestantism), which clearly affected the data concerning age. ${ }^{83} \mathrm{~A}$ candidate for the pastorate did not have to undergo an examination before the consistory until he had already been presented by the church patron. As a result this examination became merely formal. In many places this procedure did not change until the pietistic reform impulses of the later seventeenth century or the Enlightenment of the eighteenth century. ${ }^{84}$ The candidate who had been presented and examined was installed in his position at a worship service; only after this did he receive the document officially bestowing the pastorate (Lehnbrief) which guaranteed him the income from the position.

In Protestantism as well the early-modern meshing of traditional factors with those that led to change remained a characteristic of clerical office. One can speak of "professionalization" in the sense of modernization theory only toward the end of the eighteenth century. The bestowal of church office remained too closely linked to clientage and familial concerns, and in Protestantism it continued to be seen as a means of providing support-in other words, a prebend. In numerous territories of the Old Empire-unlike in Württemberg-patronage rights remained in the hands of noble families, city councils, or the parish

81. On variations in length of study, cf. Schorn-Schütte, Evangelische Geisflichkeit, chap. 3. Among other factors, the cost of education led to varying levels of clerical education within the Protestant clergy, as Strom has rightly stated, "Orthodoxy and Reform," 78-79, and the establishment of scholarships provided only limited assistance.

82. It is emphasized that all calculations provided here are only approximations. Because there was no formal degree, the duration of study can often only be estimated.

83. Cf. the discussion in Schorn-Schütte, Evangelische Geistlichkeit, 199-210; Titze, "Ueberfüllung;" Wahl, "Karriere, Kinder und Konflikte," 88ff.

84. Cf. Schorn-Schïtte, "Zwischen 'Amt' und 'Beruf'," with regard to some Hessian territories as well as Württemberg and Braunschweig-Wolfenbüttel in the eighteenth century. 
itself, so that a centralized policy of appointment was unthinkable. ${ }^{85}$ Individuals tried to influence appointment to a parish position by using various career strategies, and local political decisions concerning appointments were often scarcely affected by the will and/or the influence of the territorial ruler.

The analysis of how clergy were integrated into groups by marriage and education sheds light on this mechanism. Even though the thesis of the clergy's exclusive self-recruitment has been discredited, the social networks established by family and stages of education were decisive for the bestowal of office and prebend. Studies at the regional level have shown that the majority of clergymen married within three months after assuming their first office. ${ }^{80}$ This demonstrates on the one hand that the "arrangements" for such marriages had begun some time before the official placement in office, although this was everywhere regarded as "indecent." On the other hand, it is clear that the new pastor knew very well how important a wife was for the practical organization of the parsonage and how significant the choice of marital partner was for the social recognition of the new officeholder. It was not, however, always the rule that the search for office was combined with a marriage that would lead to a position. Similarly, regional studies have shown that appointment to office was often made easier on the basis of contacts that had been established at school, university, or in educational travels. ${ }^{87}$

A comparison of the economic situation of the clergy of both confessions in the Old Empire confirms the gradually emerging view that the pastorate was firmly integrated in the agrarian structures of the early modern period. The Council of Trent expressly required Catholic pastors to live in their parishes, which meant that a pastor also had to be able to support himself from his parish income and he could not hold several prebends. This was accomplished over the course of the seventeenth century. Urban pastors, but even more so rural pastors, shared the yields of daily agricultural activity with their parishioners insofar as they cultivated their lands themselves, with or without the help of servants. Even those clergy who rented out their fields and property remained firmly integrated into the cycles of the agrarian economy. In Protestantism as in Catholicism, the pastor's income from the early modern parish remained bound to the structural principles that had developed during the Middle Ages. The problems that arose from this could be only partially solved, since on the one hand the complexity of the pastor's sources of revenue made it difficult to secure his income, and on the other it led to conflict between parishioners and pastor, because the pastor stood in a continuous role conflict between the expectations of the clerical model and the pressures that are associated with

85. This must be particularly emphasized against the otherwise stimulating argument in Wahl, "Karriere, Kinder und Konflikte," 67ff.

86. Cf. ibid., 97-132; Schorn-Schütte, Evangelische Geistlichkeit, 295-304.

87. Schorn-Schütte, Evangelische Geistlichkeit, 162ff. 
supporting oneself from agricultural activities. ${ }^{8 x}$ This remained a continual source of conflict in Protestantism and Catholicism.

The income of both Catholic and Protestant clergy at the local level consisted of the yields from land and property that had long ago been given to the parish, from the tithe, and from taxes and fees for clerical services; in addition the parsonage, with its garden and/or fields and meadows (one can appropriately speak of a pastor's farmstead) provided the basic support for the pastor. ${ }^{89}$ This economic foundation could vary considerably between regions, Even within the confessions there were tremendous differences and everywhere there were poor and wealthy parishes; in the large cities of the empire or of the territories, cash income played a certain role. In general, however, the monetarization of clerical income began to develop over the course of the eighteenth century and did not reach its conclusion in many places until the nineteenth century. The income of the pastors of both confessions therefore depended to a high degree on the agricultural economy, on the ability and the willingness of the parishioners to deliver their goods, and on population growth, since the payment of fees for clerical services increased with the number of inhabitants. Fluctuations in income were the rule, and nowhere can one speak of "the development of a unified payment system based on education, age, and experience."

"Truly poor pastors were therefore the exception." ${ }^{.11}$ This statement appropriately describes the situation within both confessions from the beginning of the seventeenth century, a time in which the situation of the Protestant pastor, who had a legitimate family to raise, slowly began to stabilize. In Catholic areas there were differences in income especially between pastors and chaplains or vicars; ${ }^{92}$ in Protestant areas the differences existed above all between urban and

88. This problem occurs in contemporary literature on the Catholic clergy from the seventeenth century and on the Protestant clergy in the eighteenth century under the headings "Verbauerung des Klerus" or "Vom Sinken des Geistlichen Standes;" cf. on the former Holzem, "Religion und Lebensformen," 249f., and on the latter Schorn-Schütte, "Zwischen 'Amt' und 'Beruf.",

89. The details have been examined on a regional basis but have yet to be presented in a comparative overview: for the bishopric of Trier, Hahn, Rezeption des tridentinischen Pfarrerideals, 134-253; for a Bavarian village R. Beck, Unterfinning: Ländliche Welt vor Anbruch der Moderne (Munich, 1993), 460-72; on the bishopric of Osnabrück. Freitag, Pfarrer, Kirche und ländliche Gemeinschaft, 202-11, with informative tables; on the prince-bishopric of Münster, Holzem, "Religion und Lebensformen," 249-59, likewise with informative statistics. On the Protestant areas of the Old Empire (using the examples of Hesse-Kassel, Braunschweig-Wolfenbüttel, and the city of Braunschweig), cf. Schorn-Schütte, Evangelische Geistlichkeit, 49-83; on Württemberg, Wahl, "Karriere, Kinder und Konflikte," 39-43; on Rostock, cf. Strom, "Orthodoxy and Reform," 45-63. Strom confirms my findings on the income of the city clergy in his comparison of cash payments with income from fees for official duties.

90. The expectation characterized in this way by Freitag, Pfarrer, Kirche und landliche Gemeinschaft, 206.

91. Holzem, "Religion und Lebensformen," 258.

92. Cf. Freitag, Pfarrer, Kirche und ländliche Gemeinschaft, 215-20 and Holzem, "Religion und Lebensformen," 259-63. 
rural clergy. ${ }^{93}$ Comparisons with the income of parishioners in city and countryside proves that in general the rural clergy were sufficiently provided for. On the basis of income the urban pastors often belonged to the same level as city councilors or lawyers employed by the urban magistrate. ${ }^{94}$ Those who held positions of ecclesiastical leadership could negotiate increases in salary with the appropriate patron. The differences in income that existed are less obvious as a measure of place within the church hierarchy; they reflect instead the differential endowments of individual parishes that in most cases continued to exist after the Reformation.

4. A comparison with neighboring countries confirms the picture sketched above for both confessions. Research on the clergy of post-Reformation England has set a methodological standard. In the late 1970s, R. O'Day reopened a discussion of the character of clerical office in early modern England with her thesis concerning the development and establishment of a professional field (an emerging profession). ${ }^{95}$ P. Collinson has raised two reservations concerning O'Day's evaluation of the new Anglican and/or Puritan clergy as a group whose professionalization led to the transformation and differentiation of early modern English society from the end of the sixteenth century. First, when measured according to the standards of the early modern period, the clergy could already be regarded as a "profession" during the Middle Ages. ${ }^{96}$ Second, it should be stressed that the consolidation of the clergy as a social group occurred at the same time as a revival of a "clerical self-consciousness" reflecting the internal networks that had developed among this group. ${ }^{97}$

The contrast between these two interpretative frameworks is clear: for one side the formation of a "profession" in the early modern period was evidence of the modernization of the social order, for the other side it is evidence for the formative power of tradition. Further research in social and educational history has led to a mediating position between these two views. In fact, there is an impressive improvement in the level of education of the clergy (of all denominations), so that by the end of the sixteenth century the majority of pastors had a university degree. "The policy of educating the clergy thus bore fruit on the eve of the Civil War in practically the whole of England." level of education did not, however, correspond to the financial endowments of

93. Schorn-Schütte, Evangelische Geistlichkeit, 227-86.

94. With regard to the purchasing power of clerical income in the sixteenth and seventeenth century, Hahn states that a priest earned as much by reading a mass as a laborer earned per day, Rezeption des tridentinischen Pfarrerideals, 200-1.

95. O'Day, The English Clergy.

96. P. Collinson, The Religion of Protestants (Oxford, 1982), 98f.

97. Ibid., 114-15.

98. Cf. Barrie-Curien, "The English Clergy," 452, who refers to the results of various regional studies of dioceses close to and far from universities.

99. Ibid., 452. 
clerical office: at the end of the sixteenth century 40 percent of them were characterized as inadequate. This fact encouraged the competition for wellendowed prebends that was increased during the first decades of the seventeenth century by a rising number of qualified university graduates. For this reason patronage and personal connections continued to play a dominant role in the allocation of clerical positions.

Changes to the institutional structure of the church, including the dissolution of the monasteries, led in England not to the elimination but rather to the consolidation of patronage. Before the implementation of the Reformation in the diocese of Lincoln, for example, 40.5 percent of the rights of patronage belonged to the monasteries, 35.5 percent to individual noble families, and only 4.9 percent to the king; after the dissolution of the monasteries the percentage of noble patronage rose to 55.5 percent and that of the king to 21.5 percent. It is well-known that the royal house profited from this redistribution of property and the attached rights, but the chief winner of the Reformation was the gentry. There was no centralization of power with the help of a "Reformation from above"; for this reason one must be careful in characterizing the long-term improvement in clerical qualifications as an expression of the government's desire to discipline. The predominantly aristocratic patrons remained concerned strictly with their regions and for the most part appointed to their parishes clergy who were from that region or were ready to conform to the theological and political expectations of the patron. The conflict between Puritans and Anglicans as a conflict between crown and gentry is repeatedly concretized at this level; rights of patronage became a means of ecclesiastical politics, a development that also occurred on the Continent.

The decrees of the Council of Trent were difficult to implement not only in the Catholic areas of the Old Empire; the same applies to France, Italy and, Spain. The reason for this is the continuation of traditional institutions, for example the system of patronage. "Bishops and church authorities were both obliged to, and proved perfectly capable of, working within traditional institutions and the beneficesystem to produce change." "Int In southern France and in parts of Italy and Spain the clergy were appointed not by the bishop or the curia but by the local holders of patronage rights and the administrators of the benefices. It was therefore extremely difficult for reform-minded bishops to make sure that the formal prerequisites for the appointment of pastoral clergy were met. ${ }^{101}$

The decisive prerequisite for appointment was certification of education in a seminary, as had been decreed at the Council of Trent. As a rule the dioceses lacked the money to establish episcopal seminaries of sufficient quality. For example, all of the foundations in France from the later sixteenth century

100. Bergin, "Between Estate," 78.

101. Julia, "Il prete," $400 \mathrm{ff}$. 
declined during the religious wars of the seventeenth century, nor did the episcopal foundations of the eighteenth century develop beyond the standards of an academic gymnasium. ${ }^{102}$ Furthermore, they were regarded as competition by the existing educational institutions, above all by those supported by regular orders, who hindered them in their work and refused to cooperate with them. ${ }^{113}$ As a consequence, especially in France, the schools of the Jesuits, the Franciscans, and others trained a high proportion of future pastoral clergy, with the result that what was taught there was largely removed from the bishop's influence. The gradually increasing episcopal supervision over the allocation of prebends that took shape with the help of a concurrence of interest between episcopal and royal power from the end of the seventeenth century gave ecclesiastical authorities the possibility of supervising the qualifications of the clergy. ${ }^{194}$ Over the course of the seventeenth century the satisfaction of certain minimal qualifications (minimum age at first consecration, certification of a minimum level of education at an academic gymnasium) were implemented as a prerequisite for the acceptance of clerical office. As in Protestant England, how well these minimum qualifications could be put into practice in Catholic France depended on the extent of the patronage rights possessed by the bishops or the king. In many dioceses the bishops controlled three quarters of all patronage rights, in others at most ten percent. Regional studies show that in those dioceses where the majority of the patronage rights lay in the hands of the church, the more extensive requirements were implemented in the form of the so-called concours ${ }^{1115}$ over the course of the seventeenth century. This practice spread among other patrons (nobles, parishes, etc.) from the early eighteenth century. ${ }^{106}$ It was not the dissolution of the early modern system of clientage and prebends that led to an improvement in the levels of clerical education, but rather the linkage with the bishops' possibilities of supervision that focused first of all on demonstrating a minimum level of financial support from the candidate for the priesthood. These "ordination titles" also had a long-term impact in the Old Empire.

Unlike in France, the training seminaries of the regular orders Italy as well as in Spain were thoroughly integrated into the individual dioceses. As a consequence the bishops participated more extensively in establishing the clerical and spiritual contents of what was taught. ${ }^{107}$ The tremendous increase in the number of candidates for the priesthood in these countries led in Italy to the

102. Bergin, "Between Estate," 82-83.

103. Julia, "Il prete," $410 \mathrm{ff}$.

104. "... there is no doubting the solidity of the episcopal-royal alliance for the strengthening of episcopal authority." Bergin, "Between Estate," 78.

105. The concours required proof of basic theological knowledge as formulated by the decrees of the Council of Trent.

106. Bergin, "Between Estate," 81.

107. Cf. the evidence in Julia, "1l prete," 440. 
extension of episcopal seminaries from the mid-seventeenth century. Financing these seminaries was and remained a serious problem. Opening the seminaries for the laity, who had to pay a fee for attendance, provided some financial relief. ${ }^{108}$ To what degree the formal contents of education were realized in practice, and what effect they had on new clergy are questions that have not been sufficiently researched for either Italy, Spain, or France. Contemporary literature reveals that the Tridentine ideal of the pastor bonus was disseminated in these countries. In view of the unquestionable surplus of priests, whether this in fact led to the sacerdotalizzazione ${ }^{109}$ as maintained in the research cannot be determined on the basis of the predominantly normative sources.

\section{Pastor and Congregation}

The expectations of an exemplary life implicit in the concept of "clerical conduct" were not a new demand that the laity first made of the clergy during the reformatory movements of the early sixteenth century. It is well known that such demands, hopes, and expectations stood in a long tradition of criticism of the clergy that stretched back to the Middle Ages but were not necessarily connected to anticlericalism. On the contrary, the persistent expectations can be better interpreted as hope for the pastor's improvement.

The criteria according to which the clerical ideal was formulated and measured remained essentially unchanged, because they were drawn from the "norms" of the Old and New Testaments: pastoral care, intercession, and proclamation of the Word, which included the clergy's functions of admonition and warning. Since, however, Protestants denied the necessity and legitimacy of a clerical estate and stressed instead the equality of all human activity as worship, the clergy became integrated into the daily world of the faithful; the clerical estate was robbed of its sacral character in Protestantism. ${ }^{110}$ In opposition to this, the Council of Trent strengthened the dogmatic basis of the priesthood: on the one hand, the sacral character of the priesthood transmitted through ordination, and on the other the sacrificial nature of the mass, which only the ordained priest had the right to celebrate. ${ }^{111}$ The remarkable consequence of this difference was the reversal of that which served as the ideal clerical way of life in the other confession: while Protestants understood the ideal as the model "living out" of everything that other pater- and materfamilias experienced, Catholics conceived this ideal precisely as a way of life that lay outside the normal life of the parish. The priest was raised above daily life by his celibacy and was a model

108. Details in Fantappié, "Istituzioni ecclesiastiche."

109. On this term, cf. Turchini, "La nascità del sacerdozio."

110. On the conception of office in Protestantism, cf. "Amt," TRE 2: 552-621.

111. Cf. Jedin, "Das Leitbild des Priesters," 110 and 115; Holzem, "Religion und Lebensformen," $238 \mathrm{ff}$. 
in the sense of being removed from the world. Opposed to this, the Protestant pastor, as "father of the parish" was to be the best "father of the family." He was not removed from the daily life of the parish but was a part of it in a distinctive way, because he was expected to be perfect. Corresponding to this, the perceptions of self and of office by the Catholic clergy "concentrated on their sacramental power," 112 while the "special self-consciousness" (Sonderbewusstsein) of the Protestant clergy from the mid-sixteenth century, citing the practice of early Christian congregations, began to emphasize the special erudition and model behavior of the "bishops" in their daily conduct. ${ }^{113}$ It is therefore remarkable that in Catholicism as well the image of the "good shepherd" was taken up as a pastoral ideal, which was marked by the humanist return to the church fathers and which reflected their ideal of a bishop. ${ }^{114}$ The realization of this image began, as mentioned above, at the beginning of the seventeenth century in the wake of the Catholic reform. Whether, and if so, when, there were any mutual influences here between the two confessions has not been studied.

At any rate, the theological differences did not have the wide-ranging consequences that one might expect for the relationship between pastor and congregation. To be sure, the confessional differences that the pastor maintained and embodied were obvious and visible in the form of the legitimate pastoral family in Protestantism and the priest obliged in principle to celibacy in Catholicism; there was, however, no change in the interactions between pastor and parishioners. This was due to the fact that Protestantism maintained unchanged the tight interlocking of economic dependence and clerical duties that marked the daily life of the parish and could make the pastor into the structurally-disadvantaged petitioner of a congregation more inclined to refuse than to fulfill its obligations. "All spiritual contact between clergy and congregation remained caught in an interpretive network of services offered and reciprocated", "15 this applied to Protestantism as well. The pastor's office created distance and demanded respect, since he was seen as the representative of ecclesiastical authorities on the one hand and of secular authority on the other. At the same time, however, he was also a part of the parish, for like all the rest he was integrated into the traditional subsistence economy of the early modern period. The qualitative increase in demands placed on the office from the end of the sixteenth century did not change this. Conflicts always broke out where the "otherworldly" duties of the clergy had to be compensated by "this-worldly"

112. Holzem, "Religion und Lebensformen," 239; cf. also the similar interpretation in the essay by Dürr in this issue.

113. On the development of a clerical conception of office in Protestantism, cf. J. Baur, "Das kirchliche Amt im Protestantismus," in Das Amt im ökumenischen Kontext, ed. idem (Stuttgart, 1980), 103-38, as well as the article "Amt" in TRE.

114. Jedin, "Das Leitbild des Priesters," 110 and 115.

115. Holzem, "Religion und Lebensformen," 266. 
duties, mostly of an economic nature, by the congregation. What the pastor considered as the necessary condition for his pastoral-admonitory activity could be experienced by the parishioners as a burdensome obligation, especially when there were shortages. The clergy's demands for economic support could be seen by the congregation as greed and lack of compassion toward the poor!

For understandable reasons these demands were increasingly advanced in Protestant parishes at the end of the sixteenth century; because the pastor was normally married, he had greater material needs that could not as a rule be covered out of existing parish income. These conflicts reveal not only opposing legal claims but even more opposing conceptions of the relationship between pastor and congregation. While the parishioners repeatedly called on established tradition, the Protestant pastors emphasized their rights on the basis of the territorial church ordinances. On the other hand, long-recognized but apparently insoluble arguments continued over the equivalence of spiritual and material services. An example of this structural problem comes from one north German congregation in the early seventeenth century that equated a model life with contentment regarding material circumstances. In opposition to this, the pastor held that the sufficient material support of the pastor was the Christian duty of the congregation, since this expressed the respect commanded in the Bible for the clerical office. ${ }^{116}$

The social distance especially between pastor and rural parish that proved to be a supraconfessional reality from the early seventeenth century could aggravate these conflicts. Thus the demands of a north German pastor in the first decades of the seventeenth century for the payment of the appropriate tithes led to expressions of displeasure and refusals to pay from his congregation. They justified their actions by arguing that the pastor thought he was better than he actually was, because his demands showed that he had no knowledge of agricultural yields and the difficulties of producing them. Moreover, it was not fitting for a clerical gentleman to make material demands; it was much more his duty to practice modesty, especially when his congregation was suffering want. ${ }^{117}$ Similar conflicts are frequently recorded in Catholic parishes; in the seventeenth century they were repeatedly the topic of printed sermons, ${ }^{118}$ which were obviously presented as offering possible solutions.

The relationship between congregation and pastor, so fraught with conflict, was not relieved of its potential for conflict by either the Protestant or the Tridentine clerical ideals. Instead, these placed the pastor under the congregation's constant oversight of his conduct in life and in office, and in the case of the Protestant clergy extended to his entire family. It is not exaggerated to

116. On the details of this conflict cf. Schorn-Schütte, Evangelische Geistlichkeit, 272-73.

117. Ibid., $365 \mathrm{ff}$.

118. Cf. E. Moser-Rath, Dem Kirchenvolk die Leviten gelesen: Alltag im Spiegel süddeutscher Barockpredigten (Stuttgart, 1991), $187 f$. 
describe this as a relationship that could be marked by mutual distrust. ${ }^{119}$ The credibility of the clerical office and thus its suitability for implementing the political interests of the secular authority depended essentially on the credibility of the officeholders. Their religious and moral education became the central concern of both secular and ecclesiastical authority. In this respect it cannot be said (to cite the remarkable thesis of Holzem) that the Catholic church was concerned with "the establishment of an even level of subjection that was to begin with the clergy and extend to the laity." 120 It was much more concerned to make visible their prominence, in order to establish religious boundaries and barriers between the estates and to legitimate them by referring to their Biblical justification. This position could also on occasion be directed against the secular authority itself; at the least it was no guarantee for the smooth mediation of social disciplining.

There could in principle be no corresponding development within Protestantism because the clerical office did not have this sacral character. For this reason research has painted the picture of the pastor as faithful to the magistrate who functioned as an agent of secular and ecclesiastical supremacy by demonstrating his exemplary character in his role as subject. Too little attention is paid, however, to the development in practice of an independent image of self and of office that could be turned against the secular authority as well as against the demands of the congregation that were regarded as inappropriate for the office. This special self-consciousness of the Protestant clergy, legitimized with reference to the traditions of the New Testament and its continuity with the doctrine of the three estates, developed from the last third of the sixteenth century into another source of conflict between pastor and congregation. It could equally serve as a point of integration between the two, however, insofar as it was directed against claims of the secular authority that were also regarded as inappropriate by the congregation.

\section{Perceptions of Office and of Self in Confessional Comparison}

The image of the pastor as an "agent of state," which has long been used to characterize both Protestant and Catholic structures, must be revised. Even though the Protestant, and later the Tridentine Catholic, church ordinances gave the clergy a regulatory function that suited the needs of the secular authority, this by no means excluded a critical attitude toward that authority within either confession. In both Protestantism and Catholicism the justification of the clergy's central function to guard and admonish the church-and of the secular authority as its member-developed in the context of a developing

119. Holzem, "Religion und Lebensformen," 265.

120. Ibid., 277. 
theological-political model that contemporaries called the politica christiana, the doctrine of the Christian state. ${ }^{121}$ Its existence can be demonstrated through the second half of the sixteenth and the seventeenth centuries throughout Europe, as research has shown especially for France, England, the northern Netherlands, Poland, Bohemia, Sweden, and the increasingly independent Swiss Confederation, appearing in the form of an intensive conflict over the right of the estates to participate in the exercise of authority. ${ }^{122}$ The development of this politica christiana, including its practical political effectiveness, is still controversial and little-examined for the Old Empire. The conception of the loyalty of the clergy of both confessions to the secular authority has hindered research in this direction for decades.

Certainly within the Protestantism of the Old Empire there was intensive discussion concerning the understanding of political authority, its functions, rights and duties, that characterized these as a part of the Christian order of creation and salvation and therefore was seen as anything but a separation of politics and religion. During the Interim crisis of 1548 the political disagreements, which had already began to form during Luther's lifetime, came out into the open. ${ }^{123}$ The Magdeburg Confession of 1550 , for example, formulated a theological justification of the relation between the spheres of authority in the world that on the basis of the doctrine of the three estates assumed a mutual obligation and oversight of secular and spiritual authority, of church and world, that was grounded in the unity of the order of creation. ${ }^{124}$ This laid the basis for the Protestant understanding of clerical office. The tremendous conflict over the

121. On the state of research, see Schorn-Schütte, Evangelische Geistlichkeit, 390-432. A tremendous amount of contemporary literature (sermons, pamphlets, etc.) make up the textual base; the term itself appears in Chr. Warner, Prudentia Politica Christiana, Gosslar, 1614 (copy in the Herzog August Bibliothek [henceforth HAB] Wolfenbüttel and in the Staatsbibliothek Munich). I am preparing a monograph on this topic. $H$. Dreitzel gives a competent classification of the politica christiana in Protestant and Catholic theological discussion, Monarchiebegriffe in der Fürstengesellschaft: Semantik und Theorie der Einherrschaft in Deutschland von der Reformation bis zum Vormärz, 2 vol. (Cologne, 1991), 2:484-500.

122. As summary reference to the literature, see Q. Skinner, The Foundations of Modern Political Thought, vol. 2 (Cambridge, 1978); J. H. Burns, ed., The Cambridge History of Political Thought, 1450-1700 (Cambridge, 1991). On Graubünden cf. the excellent study by Pfister in this issue.

123. On the Interim as an imperial political event, see the foundational study by $\mathrm{H}$. Rabe, Reichsbund und Interim: Die Verfassungs- und Religionspolitik Karls V. und der Reichstag von Augsburg $1547 / 48$ (Cologne, 1971). On the aspect of interest here, there are only studies of individual south German imperial cities; its significance for the northwestern part of the empire has recently been examined for the first time in a volume of essays, B. Sicken, ed., Herrschaft und Verfassungsstrukturen im Nordwestern des Reiches: Beiträge zum Zeitalter Karls V (Cologne, 1994). I. Mager and W. D. Hauschild consider the significance of the Interim for the development of theological argumentation in this volume. Studies of regional conflicts concerning the Interim all date from the late nineteenth century; the exception is the stimulating study by B. Nischan, Prince, People and Confession: The Second Reformation in Brandenburg (Philadelphia, 1994).

124. On the Magdeburg Confession see C. G. Schoenberger, "The Confession of Magdeburg and the Lutheran Doctrine of Resistance," (Ph.D. diss., Columbia University 1972). There is no other research on the theological-political importance of this confession. 
right to resist the Interim that was carried out not only in the south German imperial cities but throughout the Old Empire demonstrates how current and how practically effective this view of office was among Protestant clergy already by the middle of the sixteenth century.

The Council of Trent confirmed the sacral character of office for Catholicism, thereby also confirming the unity of the order of creation and salvation as the basis for the relationship between secular and spiritual authority. In both confessions the obligation of the secular authority as the custodia utriusque tabulae was binding. For Protestants as for Catholics, this meant that the Christian ruler did indeed have a special responsibility for the securing and the strengthening of the church, but at the same time he was obligated to respect the sphere specific to the church. Both confessions set limits to political power-in the context of the Christian doctrine of the state-with the foundational principle that subjects owed their obedience first to God, then to the monarch. ${ }^{125}$ In both confessions it was the duty of the clergy to watch over this order and to admonish the secular authority, just as they did other church members, to carry out their responsibilities.

The theological-political rationale for the character of the ruling order as a monarchia temperata did differ between confessions. While in Catholic doctrine monarchy, in parallel to the hierarchical order of creation, was seen as the natural form of the state, Protestant variants of the Christian doctrine of state proceeded from the analogy of monarchical rule with the patriarchal family. The cosmological theory of monarchy within renewed Catholicism observed the prince as the image and representative of God, who in his person was appointed only mediately by God; only the pope was appointed directly in office and person. ${ }^{126}$ In the Protestant conception of authority the prince was seen as father. ${ }^{127}$ These views had consequences for the constitutional structures of both confessional churches and thus for the determination of the relationship between church and world. The Catholic Church was a monarchy under the vicarius Christi in terris, who was pater regum et principum. In his work De officio principis of $1619,{ }^{128}$ the Jesuit Cardinal R. Bellarmine (1542-1621) derived from this a fourfold subordination of secular rulers: first under the authority of

125. Cf. the references in Dreitzel, Monarchiebegriffe, 484.

126. This outline follows ibid., 488-500, who gives further references.

127. Cf. Schorn-Schütte, Evangelische Geistlichkeit, 390-415 with individual references; Dreitzel, Monarchiebegriffe, 489.

128. R. Bellarmine, De officio principis christiani libri tres (Rome, 1619), 1-38; cf. Dreitzel, Monarchiebegriffe, 495 and n. 63. On Bellarmine's doctrine of government see most recently R. Bireley, The Counter-Reformation Prince: Antimachiavellianism or Catholic Statecraft in Early Modern Europe (Chapel Hill, 1990), 136, 219. Bireley's work is central for the significance of the politica christiana in Catholic theological-political thought discussed here. There is not yet a comparative analysis of Protestant and Catholic printed works of the sixteenth and seventeenth centuries on this topic (e.g., Regentenspiegel, Hausväterliteratur). 
God, second under the authority of the pope, third under the rule of his current confessor, and fourth under the authority of his own conscience. The clergy exercised their functions as overseers and guardians in their roles as confessors and advisors to the prince. They were to direct not only his (private) conscience, but also his exercise of office as Christian prince.

Protestants characterized this type of constitution as tyrannis in ecclesia; the pope's claims to overlordship were the subject of a sharp polemic at the end of the sixteenth century from, for example, the superintendent of BraunschweigWolfenbüttel, M. Chemnitz (1522-1586) and the Hessian theology professor B. Mentzer, Sr. (1565-1627), both of whom explicitly criticized Bellarmine. ${ }^{129}$ In opposition to the Catholic position, Mentzer, Chemnitz, and a series of other orthodox Lutherans posed the conception of the church governed by the three estates (as ecclesia externa and interna) that had begun to develop from the mid-1520s, received broad diffusion in the formulations of the Magdeburg Confession, ${ }^{130}$ and was further elaborated in the late sixteenth and seventeenth centuries. Status ecclesiasticus, politicus, and oeconomicus, each with its own specific duties and rights, governed together in a kind of "separation of powers." This government was aristocratically organized: the interna were conducted by the status ecclesiasticus, the externa by the status politicus and oeconomicus. From this latter derived the secular estate's duty of caring for the church, which included the protection from compulsion in faith and confession. It was the duty of the status ecclesiasticus to secure this right, which therefore included the right to criticize any authority who did not carry out its duties and threatened to become an unchristian authority. ${ }^{131}$

These general views of how Protestant and Catholic clergy viewed their office and themselves in their relations with the secular authority were clearly the product of a few learned theologians. It can be shown that these views influenced the concrete conflicts between "normal" clergy and secular authorities, but individual cases have been too little examined. A few brief references to these conflicts in the sixteenth and early seventeenth centuries demonstrate the virulence of the politica christiana.

In response to pressure from Emperor Charles $V$ to accept the Interim, in countless Protestant territories and imperial cities refusal led to resistance from the territorial or urban magistrate together with their Protestant theologians or formulated by the theologians as a challenge to their rulers. The 1548 work (published in 1551) of the Andernach (Niederrhein) pastor S. Cephalus, was

129. On the understanding of office in Chemnitz and Mentzer cf. Schorn-Schütte, Evangelische Geistlichkeit, 399-407, and I. Mager, "'Ich habe dich zum Wächter gesetzt über das Haus Israel.' Zum Amtsverständnis des Braunschweigischen Stadtsuperintendenten und Wolfenbütteler Kirchenrates M. Chemnitz," Braunschweigisches Jahrbuch 69 (1988): 57-69.

130. See the detailed references in Schorn-Schütte, "Drei-Stände-Lehre."

131. This line of argumentation can be found in countless works of Protestant theologians after the Magdeburg Confession; cf Schorn-Schütte, “Obrigkeitskritik." 
written in this context. ${ }^{132}$ Specifically referring to the doctrine of the three estates, the pastor described the duties respectively of the status politicus (der oberkeyt), the status oeconomicus (des hausvatters) and the status ecclesiasticus (eyn lerer und prediger):

The secular authority should punish a thief, murderer, adulterer, or blasphemer ... and a father ought to admonish and punish his servants and children for the sake of their lack of understanding ... Likewise a teacher and preacher ought to punish and warn against false doctrine and all kinds of sin, to resist false teachers and refute their false doctrine, and diligently warn the people about them, so that everyone knows how to protect themselves against them. He should not be afraid of their threats and their defiance. ${ }^{133}$

In the present circumstances, the public warning against the Interim was a requirement of self-defense; teachers were "responsible for offering resistance." ${ }^{34}$ Referring to the prophet Zechariah, Cephalus described the work of the clergy as that of a shepherd who, like the head shepherd Christ, had two staffs: with one staff he should console the sheep, with the other he was to discipline them. The regents and advisors who prevented the pastors from preaching the truth must be taught just like other church members who turned away from the Gospel out of fear of emperor and pope. Secular authorities who acted in this way "are clearly anti-Christian hypocrites and deniers of divine truth." ${ }^{35}$

The use of such controversial terms as "self-defense" and "antichrist" in contemporary discussion reveals the theological-political tradition that was significant for the orientation of Lutheranism as it was becoming established: the correctio principis, used as a form of argumentation throughout the Middle Ages, established a link with the medieval right of resistance granted to the political estates against a tyrant in the form of an unchristian ruler. ${ }^{136}$ Like countless other Protestant theologians, ${ }^{137}$ Cephalus also connected the doctrine

132. There is scarcely any biographical detail; cf. the meager information in the Pfarrerbuch.

133. S. Cephalus, Warer grund und gewisse beweisung das die unrecht handeln, die iren predigern gebieten, das Bapstumb mit seinen greweln nit zu straffen, wider die verkerten weltweisen Klighing und Heuchelprediger zu dieser zeit nützlich zu lesen, Magdeburg 1551 (copy HAB 172.2 Quod (6) MF), fol. C II r/v: "Die oberkeyt aber sol eyn dieb/mörder/ ehebrecher/ gotteslesterer ... straffen ... Also ist auch ein hausvatter schuldig sein gesind und kinder um ires unverstandes willen... zu schelten und zu straffen ... desgleichen ist eyn lerer und prediger schuldig falsche lehr und allerley sünden zu straffen/ darfür zu warnen/ und den falschen lerern zu widerstehn/ ire falsche lehr $\mathrm{zu}$ widerlegen/und fleissig die leut für inen zu warnen/ uff das sich yederman für inen wisse zu hüten. Er sol sich für irem trutzen und drewen nicht entsetzen."

134. Ibid., fol. F II $r$.

135. Ibid., fol. G IV r.

136. Cf. the informative essay by K. Schreiner, “' Correctio principis': Gedankliche Begründung und geschichtliche Praxis spätmittelalterlicher Herrscherkritik," in Mentalitäten im Mittelalter: methodische und inhaltliche Probleme, ed. F. Graus (Sigmaringen, 1987), 203-56.

137. Cf. the references in Schorn-Schütte, Evangelische Geistlichkeit, 394-99. The list of pastors can easily be expanded, because there is not yet a comprehensive study of acts of resistance; I am 
of the three estates as legitimization of correction through Protestant theologians with the characterization of the Catholic emperor as an "unchristian authority" and the pope as antichrist. Thus the political-theological tradition was applied to the current situation with the help of a familiar political vocabulary. Proceeding from the conception of the right of resistance upheld by Bugenhagen and Amsdorf from 1523, ${ }^{138}$ the basic principle of owing higher obedience to God was extended to the individual in the context of the debate over the Interim. As a type of third force, the preachers had the duty to criticize injustice publicly. Thus it is clear: religion and politics were in no way separated; for Protestant pastors the question was not one of power but of the truth. The model of political order that alone could justify this understanding of authority was the cooperation of the three estates as corpus christianum "with the word of God as the decisive authority." 139

This understanding of the corpus christianum was increasingly accepted within Lutheranism from the end of the 1550s. In view of the need for a wellordered institutional structure for the church in the cities and territories that had adopted the Reformation, it was foreordained that there would be tensions between a secular authority that regarded itself as Christian and the Protestant clergy who were gradually becoming more established both socially and theologically. The core of the conflict was the power relationship between the three estates of the church: the secular authority was only one of the three estates within the church. ${ }^{140}$ The lines of controversy are clear in the conflict between the professors of the theology faculty of the university of Jena and their territorial ruler, Duke Johann Friedrich, which came to a head in the years 1560-61. In $1557 \mathrm{M}$. Flacius Illyricus, the leader of orthodox Lutheranism, ${ }^{141}$ was called to Jena; three years later the duke and the theologian were bitter opponents. The duke issued a prohibition against preaching and publishing for Flacius and some of his colleagues because he viewed their disciplinary practices as an attack on the office of the secular authority. The theologians affected ignored the prohibition and published extensive polemical works that branded the actions of the territorial lord as the beginnings of tyranny. The

preparing a research project on this topic. Cf. T. M. Schröder, Das Kirchenregiment der Reichsstadt Esslingen (Esslingen, 1987), 131-60; F. Konersmann, Kirchenregiment und Kirchenzucht im frühneuzeitlichen Kleinstaat: Pfalz-Zweibrücken (Speyer, 1996), 238f. and 338f.

138. The memoranda of Bugenhagen and Amsdorf are printed in H. Scheible, ed., Das Widerstandsrecht als Problem der deutschen Protestanten 1523-1546 (Gütersloh, 1969), 18-20.

139. W.-D. Hauschild, "Der theologische Widerstand der lutherischen Prediger der Seestädte gegen das Interim und die konfessionelle Fixierung des Luthertums," in Herrschaft und Vevfassungsstrukturen, ed. B. Sicken, 253-64; esp. 260.

140. Basic for this discussion is M. Heckel, Staat und Kirche nach den Lehren der evangelischen Juristen Deutschlands in der ersten Hälfte des 17. Jahrhunderts (Munich, 1968); cf. esp. 139-63. Research on works by clergy from the mid-sixteenth century has made clear the need to revise dating and authorship of new legal formulations concerning the state church.

141. On Flacius cf. O.K. Olson in TRE 11, 206-14. 
status ecclesiasticus could not allow this, because God had commissioned them to witness to the truth without consideration for the power or estate of anyone who criticized them. The magistratus politicus was not the church itself, or even its head: "Gubernator politicus neque ipsa Ecclesia est neque caput eius." Decisions about doctrine and the doctrinal standards that governed conduct could only be made with the agreement of the other estates of the church. ${ }^{142}$

The fundamental characteristics of the Protestant clergy's understanding of themselves and their office briefly outlined above did not by any means lose their validity at the end of the sixteenth century. The integration of the "good shepherd" ideal drawn from the Old Testament with the understanding of the corpus christianum drawn from tradition, within which the doctrine of the three estates helped guarantee the aristocratic structure of power, remained characteristic into the early eighteenth century.

The understanding of the clerical office in post-Tridentine Catholicism was formed from very similar traditions. The ideal of the pastor bonus and the admonitory function of the ordained priest had a similar effect in practice to that of Protestantism: distance from the congregation as well as from the secular authority. In contrast to Protestantism, the doctrine of the Christian state for reformed Catholicism was characterized by the understanding of the monarchia temporata, which both limited but also legitimized hierarchical authority, and which was completely opposed to the identity of Christian and political community as conceived by estate theory. For this reason the claims of the Catholic clergy had a much more limited political effect than did those of Protestantism in connection with the idea of the corpus christianum. There were fewer controversies over the social and political place of the clergy in the Catholic ruling order than there were among Protestants during the sixteenth and seventeenth centuries. Nevertheless research on this question is only beginning. The Catholic clergy gained in authority and distance through their relation with the divine and the sacral. This had itself a disciplinary power, since an understanding of the effects of differentiation between the estates was its most important condition.

Neither Protestants nor Catholics needed to invent new institutions. Traditional authority, in this case clerical office, was so powerful that the necessary political and social integration could be accomplished with its assistance. ${ }^{143}$ Whether this can be characterized as modernization through confessional disciplining is still an open (or reopened) question. The flexibility of existing patterns of order and interpretation demanded by the sixteenth century was obviously sufficient to allow an institution such as the clerical office to develop

142. The theologians' memorandum: "Gravissimae causae, cur forma et norma Consito rei publice iam edita in pleribus portibus pie probari non possit," in HAB Cod. Guelf 11, 9, fol. 45-57. Detailed analysis of the memorandum by Kruse, Speners Kritik, $63 \mathrm{f}$.

143. Holzem reaches a similar conclusion, "Religion und Lebensformen," 428, and n. 19. 
along parallel lines that transcended confession, despite confessional differences in theological legitimization.

\section{Summary}

The discussion above can be summarized in three points that refer back to the introductory remarks.

1. On the basis of their social origin and social integration, both Protestant pastors and Catholic pastoral clergy were a part of that bourgeois group who acted in the service of the secular authority; this applies to all of early modern Europe. What the pastors' family achieved on the social level through familial contacts in Protestant areas was established through the mediated connections of extended family, clientage, and friendship in Catholic areas. The similarities are strengthened by the comparable form and contents of education and of educational institutions. Insofar as the state of research allows generalization, it seems that the pastoral clergy of both confessions had attained a comparable level of education by the seventeenth century. In Catholic areas university study was the exception but priests were required to complete their education at a seminary, whose standards surely met the qualifications for a specialized professional education. A complete course of study in theology was not the rule within Protestantism, either; having graduated from a philosophical faculty was a sufficient qualification. In comparison with the standards of pre-Reformation education, there was a clear improvement in education that can be called the early modern "path toward a profession." This, together with the development of a social and familial network, allows us to characterize the pastoral clergy of Europe during the later sixteenth and seventeenth centuries as a part of that "power elite"144 who were essential for the early modern period.

2. The formal conditions for the suitability of clerical officeholders reached cum grano salis a comparable level in all confessions throughout Europe during the seventeenth century. The disagreements concerning the evaluation of these conditions stem from the measures by which historical change is characterized. For the group of pastoral clergy examined here, the category of modernization proves to be insufficient, since there was a tendency transcending the confessions to appeal to prereformatory traditions in establishing an understanding of office. Historians must be able to describe how tradition was able both to accommodate and to be transformed.

3. From this point of view the question of the clergy's suitability for the goal of the developing modern state encompasses only half of the historical reality. The clergy and their contemporaries who comprised their congregations were

144. On terminology and concept, see W. Reinhard, "Powers Elites, State Servants, Ruling Classes and the Growth of State Power," in Power Elites and State Building, ed. idem (Oxford: Clarendon, 1996), 1-18. 
also concerned with their role as mediators of the holy, of "the religious" in the world. Clerical perception of self and of office was decisively stamped by the conviction that despite all contradictions these formed an insoluble unity. For this reason we must also consider for both confessions the broad impact of the doctrine of the Christian state, whose core was the doctrine of the three estates. In the political and social controversies of the late sixteenth century the political impulse of this doctrine grew in strength in a way more clearly seen in Protestantism than in the territories that remained Catholic. Nevertheless the concept of the monarchia temperata in the Catholic understanding of authority also gave the clergy a right to criticize the ruler. The long tradition of the correctio principis was put into practice through the clerical understanding of office in both confessions and became a very concrete reality for people in the sixteenth and seventeenth centuries. This is a typically early modern way of developing tradition further through the consensus of generations, ${ }^{15}$ whose relevance the historian of the early modern period must take just as seriously as the attempts of the secular authority to use the power elites in their own interests.

JOHANN WOLFGANG GOETHE-UNIVERSITY

FRANKFURT AM MAIN

145. On this concept, with reference to E. Shils, see B. Peters, Die Integration moderner Gesellschaffen (Frankfurt am Main, 1993), 279. 


\section{Appendix}

Table 1

Comparison of the Social Origins of Protestant Clergy Between the Duchy of Württemberg, the County of Hanau-Lichtenberg, Landgrafschaft Hesse-Kassel, Principality of Braunschweig-Wolfenbüttel, Danzig (city/territory), and Basel (city) in the Eighteenth Century.

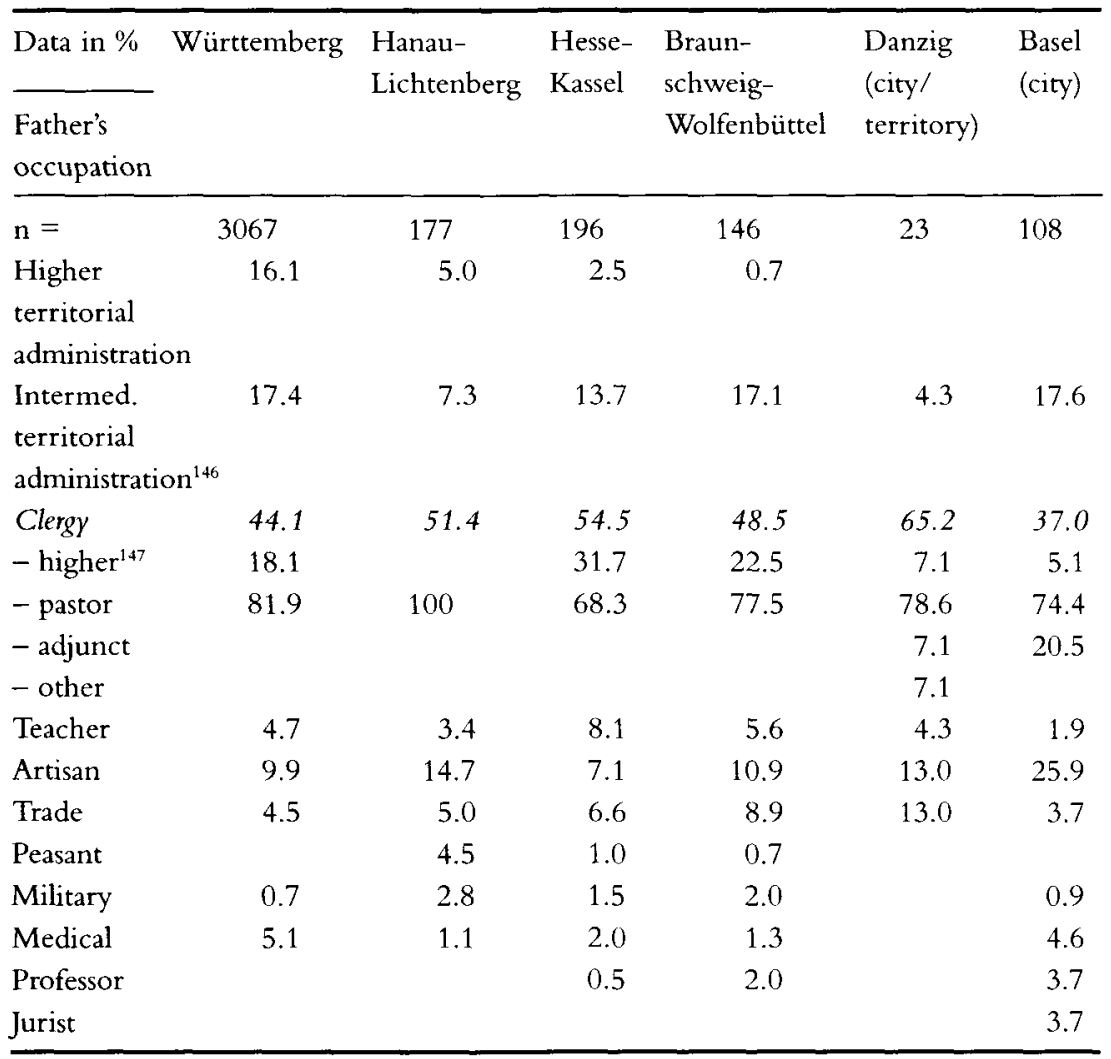

146. The intermediate territorial administration includes the city administration.

147. The following subordinate groups are included within the category of clergy. The percentage is the proportion within the clergy. 
Table 2

Comparison of the Social Origins of Protestant Clergy Between the Canton of Zurich and Basel (city) in the Eighteenth Century

\begin{tabular}{lrrrr}
\hline & \multicolumn{2}{c}{ Zurich } & \multicolumn{2}{c}{ Basel (city) } \\
Father's Occupation & $\%$ & $\mathrm{n}$ & $\%$ & $\mathrm{n}$ \\
\hline higher magistrate $^{1+8}$ & 17.3 & 72 & 13.6 & 6 \\
lower magistrate $^{\text {Clergy }}$ & 5.8 & 24 & & \\
- adjunct $^{149}$ & 41.1 & 171 & 27.3 & 12 \\
- pastor $^{\text {Artisan }}$ & & & & 3 \\
Merchant & 26.4 & 110 & 40.9 & 18 \\
Bildungsbürger & 3.8 & 16 & 4.5 & 2 \\
Mercenary & 5.3 & 22 & 9.1 & 4 \\
Jurist & 0.2 & 1 & & \\
Other & & & 2.3 & 1 \\
TOTAL & & 416 & 100 & 1 \\
\hline
\end{tabular}

Table 3

Comparison of the Regional Origins of Protestant Clergy Between

Hildesheim (city) and Danzig (city and territory) in the Sixteenth and Seventeenth Centuries

\begin{tabular}{lcccccccc}
\hline & \multicolumn{3}{c}{ Phase I: 16th Century $(\mathrm{n}=28)$} & \multicolumn{3}{c}{ Phase II: 17 th century $(\mathrm{n}=83)$} \\
& \multicolumn{1}{c}{ Hildesheim } & \multicolumn{2}{c}{ Danzig } & \multicolumn{2}{c}{ Hildesheim } & \multicolumn{2}{c}{ Danzig } \\
& $\%$ & $\mathrm{n}$ & $\%$ & $\mathrm{n}$ & $\%$ & $\mathrm{n}$ & $\%$ & $\mathrm{n}$ \\
\hline Countryside & & & 92.6 & 25 & 30.8 & 8 & 43.9 & 25 \\
City & 100 & 1 & 7.4 & 2 & 61.5 & 16 & 56.1 & 32 \\
Territory $^{151}$ & & & & & 7.7 & 2 & & \\
\hline
\end{tabular}

148. For Basel no distinction is made between higher and lower magistrate.

149. The following subordinate groups are included within the category of clergy. The n-value is the number within the total number of clergy.

150. This category includes teachers, professors (non-clergy) and doctors/apothecaries.

151. Catholic territory such as Hildesheim-Stift and Ermland is included here for the sake of comparison. 